Lebedeva, G.N. (2021). HOMO ACADEMICUS. Part I. Scientific and Public organizations of the Russian Empire: between State Responsibility and Private Initiative (in Russian). Eastern European bumanitarian collection of mini monographs. Collection of Scientific Articles. European Scientific e-Journal, 1 (7), 58102. Hlučín-Bobrovníky: "Anisiia Tomanek" OSVČ.

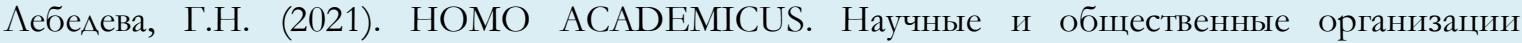
Российской империи: межАу государственной обязанностью и частной инициативой. Eastern European bumanitarian collection of mini monographs. Collection of Scientific Articles. European Scientific e-Journal, 1 (7), 58-102. Hlučín-Bobrovníky: “Anisiia Tomanek” OSVČ.

DOI: $10.47451 /$ his2020-12-006

EOI: 10.11244/his2020-12-006

The paper is published in Crossref, Internet Archive, Google Scholar, Academic Resource Index ResearchBib, JGate, ISI, CiteFactor, ICI, eLibrary databases.

Galina N. Lebedeva Candidate of Philosophical Sciences (PhD)

Associate Professor Department of Philosophy Leningrad State University

St Petersburg, Russia

E-mail: gal_le@list.ru ORCID: 0000-0002-6217-9929

\title{
HOMO ACADEMICUS
}

Part I.

\section{Scientific and Public organizations of the Russian Empire: between State Responsibility and Private Initiative}

\section{Abstract:}

Homo academicus was the title of a book by Pierre Bourdieu, published in Russia in 2017. Research of the person, his chances in the period of formation of scientific organizations - a research topic. The monograph is devoted to the development of scientific organizations of the Slavic peoples. The philosophical and anthropological grounds for the preservation of cultural heritage and creation in the Russian Empire in the 18 and first half of the 19 centuries are considered. The author traced how the scientific and practical activities of Russian statesmen and scientists formed programs and institutions for the preservation of cultural heritage. The author concludes that the processes of nation formation are closely connected with national culture, the formation of cultural centers, the dissemination of education, the press, etc. At the time of the formation of the nation, the problem of language acquires an important role - its dissemination, the creation of norms of the national literary language. Therefore, the study of culture should be combined with linguesocial problems.

Keywords:

Homo academicus, Pierre Bourdieu, scientific organizations, cultural identity, nation, cultural heritage, Imperial Russian Academy of Sciences. 
Галина Николаевна Аебедева

к. филос. н., доцент кафедры кафемра философии Аенинградский государственный университет имени А.С. Пушкина

Санкт-Петербург, Россия

E-mail: gal_le@list.ru

ORCID: 0000-0002-6217-9929

\section{HOMO ACADEMICUS}

Часть I.

\section{Научные и общественные организации Российской империи: межАу госуАарственной обязанностью и частной инициативой}

\section{Aннотачия:}

Homo academicus - так называлась книга Пьера Бурдье, вышедшая в России в 2017 году. Исследование человека, его изменений в период становления научных организаций - тема исследования. Монография посвящена развитию научных организаций славянских народов. Рассмотрены философские и антропологические основания деятельности по сохранению культурного наследия и создания в Российской империи в XVIII - первой половине XIX века. Автору удалось проследить, как научная и практическая деятельность российских государственных деятелей и учёных сформировали программы и учреждения по сохранению культурного наследия. Автор делает вывод, что процессы формирования нации тесным образом связаны с национальной культурой, складыванием культурных центров, распространения образования, печати и пр. В момент формирования нации важную роль приобретает проблема языка - его распространения, созАания норм национального Аитературного языка. Поэтому исследование культуры следует совместить с Аингвосоциальной проблематикой.

\section{Ключевые слова:}

Homo academicus, Пьер Бурдье, научные организации, культурная идентичность, нация, культурное наследие, Императорская Российская Академия наук.

\section{Введение}

Вопросы о происхождении и сущности нации, равно как и национального самосознания, культурной илентичности исторически совпали со станов ением науки и появцением научных и культурных организаций у многих народов Европы. В результате активной деятельности интелцектуалов Ава века тому назаА складывались митературные языки, в том числе и у славян, и их национальная и языковая илентичность.

Таким образом, можно констатировать, что «нация» в определённом

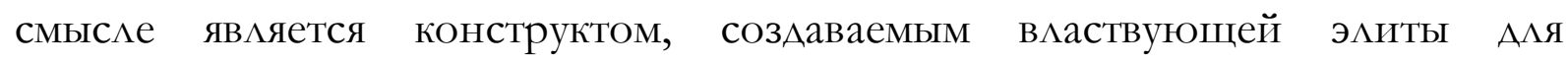


мобилизации масс и достижения собственных интересов. ПравАа, соглашаясь с тем, что призыв к национацьному единству со стороны вАаствующей элиты Аействительно является весьма эффективным, всё же обращается элита к уже существующему этносу. Но Аелает нацию из этнографического материала Аеятельность интеллектуалов. И зрелость нации выражается в наличии у неё своей академической науки со своими школами и разработанной терминологией. Полушутя-полусерьёзно историк А. Тойнбии писац, что в мире могут быть подиинно независимыми мишь те народы, на языке которых может быть написан проект и детальная инструкция по эксплуатации ядерного реактора.

И по этой причине, говоря о развитии наций в прошлом и настоящем всегда надо отдавать должное работе ученых. Можно сказать, что Номо academicus (по словам Бурдье) создают нацию не в меньшей, а может быть, и в большей степени, чем правители, полководцы и религиозные деятели.

Особенности становления наций совпали с романтизмом как художественно-эстетическим течением. Под влиянием сочинений Г. Гердера (1744-1803 гг.) о поэтической инАивидуаАьности наций («Аух народа») романтизм стац противопостав ять «себя просвещению и созАанной наукой Нового времени механистической концепции мира». В первую очередь

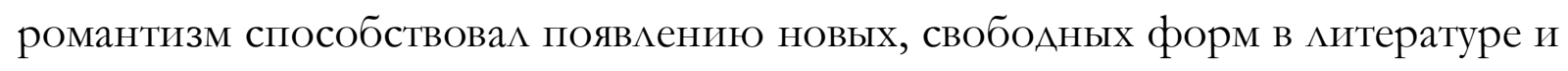
искусстве, отразивших ощущение открытости и бесконечности бытия (Романтизм, 2015). Гегель словом «романтическое» опрелелил одну из трёх универсальных «художественных форм» (наряду с символической и классической), в которых Аух, порывая с внешним, обращается к своему внутреннему бытию, чтобы там «насладиться своей бесконечностью и свободой». В целом в науке именно романтики сосредотачивали свой интерес к истории на памятниках митературной страны.

Проблемы нации и национализма как илеологии сначала связаны с национальной идентичностью, а затем с утверждением самодостаточности нации и её свободы. В Российской империи такие процессы начаАись с эпохи Петра I, и наиболее актуальными стали в деятельности государственной бюрократии вплоть Ао Октябрьской революции. Мы остановимся на периоде, когда государство было наиболее заинтересовано в создании научных организаций: этот период начинается с правления Петра I и до конца 1860-х годов, когда создавались образовательные учреждения и государство проводило по отношению к ним целенаправленную организационную и регулятивную политику. 
Связь интелцектуальной культуры наций находится в единстве с процессами образования, научных обществ, их становления и институализации во всех проявлениях, впцоть до научных организаций, университетов, академий.

Существует определённый объём источников по истории научных организаций в России. Первым по времени, и что особенно важно, обстоятельным, в 10 томах, исследованием можно отметить «Материалы Аля истории императорской Академии наук» (Сухомлинов, 1885-1900). В Новейшей истории можно отметить такие исследования по истории науки и научных организаций:

- $\quad$ Соболева, Е.В. Организация науки в пореформенной России. - $\Lambda ., 1983$;

- Самоорганизация и наука: опыт философского осмысления. Сб. ст. / Отв. реА. И.А. Акчурин, В.И. Аршинов. - М.: ИФ РАН, 1994;

- $\quad$ Аетопись Российской академии наук. Т. 1. 1724-1802 / ГА. реА. акаА. Ю.С. Осипов. Отв. реА. А.филос.н. Н.И. Невская. - СПб.: Наука, 2000;

- Артемьева, Т.В., Микешин, М.И. Интелцектуальная культура эпохи Просвещения в России / Учебное пособие. - СПб.: Санкт-Петербургский центр истории илей; ИзАательство «Политехника Сервис», 2020.

Во второй части будет рассмотрено, как происходило формирование научных обществ в славянских странах, основное современное исследование «Славянские матицы. ХІХ век» (Исламов и др., 1996).

Конечно же, учитывая широкую проблему исслелования, более важным вилится привлечение конкретных источников, которые мы будем использовать в данном исследовании.

Нация постоянно меняется, и каждой исторической эпохе соответствует свое представление о нации. В отличие от России, западные и южные славянские народы (кроме Черногории) к концу XVIII века уже несколько веков находились под чужеземным игом, их языки были сведены к простонародным. Они не имели своей государственности, а значит, и политической самостоятельности.

Нация - это самый послеАний по времени возникновения и самый сложный тип этноса. Нет Ао сих пор единого научного определения нации, а научная митература по теме нации очень разнородна и пристрастна. Кроме того, нация не явцяется чем-то неизменным ни одно и то же время Аля современников, ни с изменением времени. 
У каждой нации, например, разАичны особенности становмения языка. Во-первых, в отличие от стран Западной Европы, где вплоть до XVII-XVIII века матынь была языком церкви и науки, а нередко и вообще единственным письменным языком, на Руси с момента Крещения писали на понятном церковно-славянском языке, который к тому же был Аолгое время и разговорным. Таким образом, в странах Западной Европы образованные Аюди от Португалии до Норвегии могли переписываться и разговаривать при встрече на матыни, зато основная масса населения была безграмотна, поскольку Аля образования надо было сначала выучить мертвый матинский язык. В зрелое Средневековье, когда начали подниматься города, в которых возник крупный и влиятельный слой бюргеров, которым грамотность была необходима в хозяйственной деятельности, начала появляться митература на местных языках. Но на них писали «романы» (произведения на романских языках, а не матыни), а богословие, философия, право и медицина по-прежнему преподавались и писались по-латыни. Только в эпоху Реформации на местные национальные языки европейских народов начинают переводить научные труды, а потом и создавать оригинальные произведения. На Руси язык церкви, науки и канцелярии был свой - общепонятный церковно-славянский. Но зато Русь была отгорожена языковым занавесом от Аругих стран христианской Европы.

Понятно, что в силу обстоятельств исторического развития в России наука и философия получили распространение не в университетах, а в местах императорских резиденций, рядом с которыми складывались митературные школы. Практически все русские митераторы находились на государевой службе - и сенатор Г.Р. Аержавин, и камер-юнкер А.С. Пушкин, и кавказский гусарский офицер М.Ю. Аермонтов. Только в середине ХІХ века стали появ яться митераторы, жившие на свои гонорары. Но традиция службы на государство оставалась незыблемой. Аля Аворянина (а большинство митераторов были Аворянами «по праву состояния») считалось необходимым отслужить хотя бы немного по военной или статской службе.

XVIII век и в России, и в Европе, это - век Просвещения. В чем же сущность философии Просвещения? Как мегко заключить из названия, философы-просветители исходили из преАставления, что все беАствия, страдания и несчастья человечества обусловлены только и исключительно невежеством мюдей. Следовательно, необходимо просвещать народ. Некоторые просветители Ааже считали, что, как только количество грамотных в Европе превысит 51\% населения, сразу исчезнут все пороки и преступления. При этом сами просветители считали народ сборищем неразумных Аюдей, 
напоминающих по своему интец екту детей. Понятно, что давать народу воцю нельзя, как нельзя детям давать спички или оружие. Вся належла на философа на троне, на просвещенный абсолютизм, который будет иметь Аостаточно власти, чтобы просветить народ и не Аопустить всякие потрясения, вызываемые темнотой и грубостью социацьных низов.

У славянских народов городские верхи и аристократия были иноземными (кроме Польши), а славянское население составляло низшие слои (крестьянство и городские низы). Славяне были мишь крестьянскими обществами, расколотыми социально и религиозно. Аомая сословные перегородки, стала формироваться славянская национацьная интемлигенция и наука. В развитии науки огромную роль всегда играли и играют научные организации. У народов, которые не имеют государственности, именно научные общества замещают собой академии наук и университеты. Славянское возрождение, разумеется, способствовацо формированию и развитию научных

Можно выделить следующие шаги в создании научныхх организачий в России и у славянских народов.

В первой половине XIX века выявились сходные интересы как среди российских, так и среди славянских интелцектуалов к прошлому, собиранию и изучению Аревностей, историческому прошлому языка, и его фиксации и оформлению в виде словарей, энциклопедий. Язык воспринимался как коллективная память народа и воплощение «духа народа». Имена и биографии вылающихся ученых, внесших большой вклаА в науку своей страны, их способности и кропотАивый труА - это не только история и поиск новых знаний, но и научная информация, концепции.

Bo-вторых, по мере того как информация начинает приводиться в систему, появАяются научные организации и академии. Такая система очень хрупкая, Аля этого необходимы условия, благодаря которым возможно создание этих новых знаний.

Отметим третий фактор: Аля существования науки необходимы инициативные организаторы, которые самостоятельно, а также в Аолгой рутинной работе с чиновниками, властью и бюрократией смогли бы организовать науку и её учреждения. Наконец, по мере того как накоплен Аостаточный объём знаний, они становятся элементами школьного и университетского образования, а также превращаются в часть культуры общества. 
$B$ итоге, наука достигает такого уровня деятельности, что оформляется в самостоятельный общественный институт. Таков сложный путь получения и сохранения знания: от инициативных одиночек к построению системы.

Рассмотрим, как процесс организации науки прошел путь от общественных и частных увлечений к формированию специальных учреждений в России и у славянских народов. Важнейшим условием является язык науки, который показывает особый уровень развития не только культуры интелцектуалов, но и народа в целом. Язык науки стал предметом размышлений еще у греческих софистов, затем в эпоху средневековой схоластики. А в периол XVIII-XIX веков именно с исследования и конструирования специацьного, научного языка, формировацась затем и вся остальная наука.

Таком образом, задачей исследования было проследить становление и факторы, способствующие сохранению или исчезновению национацьных языков.

\section{1. Вопрос о происхожАения нации и национамизма}

Вопрос о происхожления нации и национализма (как проявления илеи нации в политике), является одним из «вечных» вопросов философии. Вплоть до нашего времени нет удовлетворяющего определения нации. Аитература, в том числе и философская, посвящённая возникновению нации и национальному самосознанию, настолько обширна и разнородна, что даже обозначить перечень источников практически невозможно.

В определенном смысле, елиное научное определение нации, равно как национального самосознания и национализма, вряд Аи когда-либо появится. Это объясняется историческими, географическими, конфессиональными, культурными, и многими Аругими обстоятельствами. Можно сказать, что нация не является чем-то статичным и неизменным, а всегда меняется, и каждой исторической эпохе соответствует свое представцение о нации.

Изначально возникновение наций связано с формированием группового самосознания, но в итоге - с центростремительными силами по объеАинению в еАиное государство, что явАяется особым признаком запаАной европейской истории.

В русской мысли принята трактовка нации как этноса, в отАичие от французской и англосаксонской, рассматривающей нацию как совокупность гражАан страны. 
B XIX веке понятие «нация», а также произведенные от него слова «национализм», «национальный вопрос», и пр., были ещё менее разработаны, и употреблялись нередко в ином значении, чем в наше время. Политический смыс с средневековое понятие «нация» приобрело во Франции во время революции. Не случайно сам термин «национализм» появляется в 1812 году (Кола, 2001). Во Франции это слово обозначало создание единой нации полноправных гражАан без сословных различий.

Вплоть до конца ХIX века термин «национализм»еще не утвердился не только в научной, но и в популярной митературе. Ещё в 1874 году во Франции в энциклопедическом словаре «Аарусс» слово «национализм» определялось как неологизм. Исследователь французского национализма Р. Жирарде отмечал, что в XIX веке во Франции поА национализмом понимались или напыщенная патриотическая риторика, или освободительная борьба народов старых империй. К последнему относились итальянское, польское или сербское Авижения (Фёдорова, 1997). Только в ХХ веке слово «национализм» стали употреблять очень широко, причем называя этим термином также и идейнополитические феномены прошлого. В частности, в России под национализмом подразумевалось движение малых народов против национацьного угнетения. Именно таково было понимание «национацьного вопроса» в марксистской философии. Зато в XX веке словом «национализм» начали чрезмерно зАоупотреблять.

Слову «национализм», одному из наиболее употребительных и наименее ясных в политологии, особенно не повезло в научной митературе. Западный историк А. КАарксон иронически сказал: «Национализм подобен греху - это явление настолько знакомое, что не подАаётся определению или Ааже точной характеристике» (Clarkson, 1950).

В отечественной митературе утвердилась негативная оценка национализма. Так, в Большой Советской Энциклопедии о национализме говорилось: «Национализм - буржуазная и мелкобуржуазная илеология и политика, а также психология в национальном вопросе. Национализм трактует нацию как высшую внеисторическую и наАклассовую форму общественного единства, как гармония, целое с тождественными основными интересами всех состав яющих её социальных слоёв... Аля национализма характерны идеи национального превосходства и национальной исключительности, получающие большее или меньшее развитие в зависимости от обстановки, от взаимоотношений данной нации с Аругими”. В изданном в 1983 году «Кратком политическом словаре» сказано: «Национализм - буржуазная идеология, 
политика и психология в национацьном вопросе. Аля национализма характерны идеи превосходства одного - «высших», якобы «избранных» самой природой наций наА Аругими - «низшими», «неполноценными» (Абаренков и Ар., 1983).

Примерно так же трактует национализм, изданный десятилетие спустя, совсем в иную эпоху, энциклопедический словарь по политологии: «Национализм - это илеология, психология, социальная практика подчинения одних наций Аругим, проповедь национальной искАючительности и превосходства, разжигания национальной вражАы, неАоверия и конфликтов» (Аверьянов, 1993).

Современный электронный словарь также объявляет, что «национализм гипертрофированная форма национального сознания, провозглашающая илеи национальной исключительности, замкнутости, превосходства» (Национализм, 2005).

ОАнако, чем же национализм в такой трактовке отличается от шовинизма и расизма? Борьба угнетенных наций за своё освобождение ведь тоже называется национализмом и в этом деле национализм является делом вполне позитивным. В.И. Аенин, будучи убежденным интернационалистом, тем не менее писац, что национализм, который пробуждается у угнетенной нации, имеет «историческое оправдание» (Аенин, 1958-1965).

Оппонент Аенина почти по всем вопросам, философ Н.А. Бердяев, дели национализм на агрессивный, разрушительный, зоологический, и на национализм творческий, созидательный, способный вести нацию по пути общественного прогресса. Как видим, применительно к угнетенной нации национализм имеет вполне позитивный смыс . Современные русские правые особенно ценят виАнейшего философа Русского Зарубежья И.А. Ильина и его трактовку национализма: «Национализм есть мюбовь к историческому облику своего народа во всем его своеобразии. Национализм есть вера в инстинктивную и Ауховную силу своего народа, вера в его Ауховное призвание, Национализм есть воля к тому, чтоб мой народ творчески и свободно цвел в Божием саду. Национализм есть созерцание своего народа переА мицом Божиим, созерцание его Ауши, его недостатков, его та^антов, его исторической проблематики, его опасностей и его соблазнов, Национализм есть система

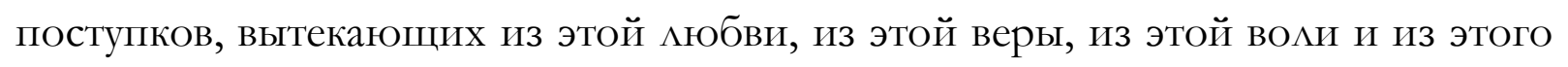
созерцания.» (И^ьин, 1992). Красиво, но непонятно, если не считать абсолютно позитивного отношения к понятию “национализм”. 
На Западе понятие «национа^изм» не имеет никакого негативного оттенка. Так, американский словарь Вебстера под национализмом понимает: «1. Преданность своему народу. 2. Защита национального единства, или независимость». Британская Энциклопедия сообщает: «Национализм: верность и приверженность к нации, или стране, когда национальные интересы ставятся выше Аичных или групповых».

Современные западные учёные также согласны с позитивным отношением к национализму. Опрелеления национализма у них принципиально не отличаются от тех, что были приведены выше. Весьма интересную трактовку национализма Аал Э. Гелмнер: «национализм обозначает принцип, требующий совпадения этнических и политических границ, а также чтобы управляемые и управАяющие внутри Аанной политической еАиницы принаАлежали к оАному этносу» (Геллнер, 1991). С этим можно согласиться, хотя национализм не исчерпывается только соединением нации в одном государстве или борьбой за этническую чистоту правящей верхушки.

Позитивное отношение к национацизму высказывац великий гуманист М. Ганди: «Национализм в моем понимании означает, что моя страна Аолжна обрести свободу, что, если нужно, вся моя страна Аолжна умереть, чтобы человечество Аолжно жить...» (Горев, 1984).

Ещё одно определение национализма дал Гасан Гусейнов в советскофранцузском «Словаре нового мышления»: «Национализм - термин, означающий приоритет национальных (этнических) ценностей как переА Аичностными, так и переА иными социальными (групповыми, универсаАьными) ценностями и применимый Аля описания политической практики, иАеологии и социально-психологической ориентации мичности» (Козцова, 1989). С определением Гусейнова вполне можно согласиться.

ГАавная причина сложностей в определении национализма заключается именно в неразработанности самого понятия «нация». Ограничимся кишь напоминанием, что существует Ава определения нации - англо-французское и немецкое. Согласно первому, нация - совокупность граждан страны. В этом смысле получившие гражАанство иммигранты сразу входят в американскую или французскую нацию. Понятно, что в США или Франции часто используется слово «национальный» (типа «национальные интересы») Аля обозначения общегосударственного. Немецкое понятие нации, («этнонационализм»), получившее распространение в России, понимает поА нацией этнос, то есть кровнородственную межпоколенную общность. Этнос не обязательно может 
иметь свою государственность и даже определённую территорию, но обладает единством крови, языка и культуры.

Итак, в России понятие «нация» является синонимом слова «этнос» и национализм в отечественном понимании яв яяется этническим Авижением.

Что же такое «этнос»? Под этносом понимается исторически сложившаяся на определенной территории межпоколенная кровнородственная общность Аюдей, облаАающих общими стабильными особенностями языка, культуры, психики, самосознания и территории (Аеонтьев, 1998), то есть пониманием своего отАичия от Аругих общностей и собственного еАинства.

По мысли известного российского советского учёного, академика Ю.В. Бромлея, этнос - специфическая социальная группа, базирующаяся на общности культуры и едином самосознании. ЕАинство обеспечивается синхронными (в пространстве) и диахронными (во времени) информационными связями. Бромлей считац, что существуют Ава виАа этноса - этникос (Аиахронные связи, то есть межпоколенная передача этнокультурной информации), и этносоциальные организации, или ЭСО (синхронные связи разАичного рода: политические, экономические, социальные, культурные).

Существуют и Аругие определения этноса, однако они принципиацьно не отличаются от приведенных выше.

Объгно въгеляют три исторических типа этноса: племя - народность - начия.

Племена возникают на самой ранней стадии человеческой истории вместе с родовым строем. Пцемя имеет общее самосознание, имя, память о своих предках (как правило, мифологизированных), язык, культурно-бытовые особенности.

Народность появляется в более поздние времена, когда сливающиеся племена складываются в государство. Если племя объединяют, прежде всего, брачно-родственные связи, то народность - территориально-политические связи, складывающиеся в пределах государства. Народность может ассимилировать многие Аругие народности, оказавшиеся связанными с нею, и сама может по историческим причинам смешаться и ассимилироваться. В результате изменения государственных границ, завоеваний, миграций, распространения новых религий, и прочих причин, народности могут исчезать, став этническим «материалом» Аля новых возникающих народностей. Так исчезли хетты, милийцы, карфагеняне, вандалы, провансальцы, печенеги и многие Аругие. Ни одна из этих народностей не была физически истреблена, они просто вАились в новые народности. 
Отчего же в мире возникают этносы? На это счёт существуют разАичные этнологические теории.

Согласно теории примордиализма, этносы существуют всегда и повсеместно, начиная с первобытного человеческого стаАа. У истоков этой теории стояли такие великие учёные, как философ И.Г. Гердер (1744-1803 гг.), считавший народ единством «крови» (происхожАения) и «почвы» (страной проживания), социолог Ф. Теннис (1855-1936 гг.). «Классические» формы теории создали ЭдварА Шимлз и Поль ван ден Берг.

ОАнако примордиализм не может объяснить «исчезновение» некоторых Аревних этносов, и создание новых. В частности, примордиалистская теория не объясняет рождение этносов с сильно выраженным чувством национальной гордости в западном полушарии или Австралии. На эти вопросы пытаются ответить инструменталистские теории. Приверженцы инструментализма в этнологии сосредотачивали своё внимание не на изучение объективной основы существования этноса, а мишь на роли последнего в культуре (Садохин и Грушевицкая, 2001).

Инструменталисты считают, что этничность Аишь теория, которую созАают элиты Аля мобилизации масс и достижения собственных интересов (Аанн, 2003). Аогика инструменталистов такова - раз этнические группы существуют, значит, это кому-то нужно. Правда, соглашаясь с тем, что призыв к национальному единству со стороны властвующей элиты действительно явАяется весьма эффективным, все же обращается элита к уже существующему этносу.

Крайности инструментацизма пытаются обойти конструктивисты, [Ф. Барт, М. Мил, Ф. Боас и Ар.] считающие, что этнос есть социальная организация, существующая за счёт воспроизводства межгрупповых границ. Конструктивисты большое внимание уделяют субъективной стороне: колмективному сознанию, мифологии, воображению. В самом деле, многие политические нации были созданы искусственным путем, не имея ни антропологического, ни языкового, ни религиозного, ни культурного еАинства. Классическим примером искусственного создания нации (и государства, созАанного поА эту нацию) являются украинцы или боснийцы.

ОАнако конструктивисты не могут игнорировать существование этносов, у которого существует самосознание при отсутствии властвующей элиты, заинтересованной в независимости.

Придется согласиться, что единой теории возникновения этноса не существует. В принципе, каждая из вышеперечисленных теорий права по- 
своему. В самом деле, многие этносы действительно преАстав яяют собой кровнородственную общность и возникли ещё в Аревности, например, русский этнос (точка зрения примордиалистов). Аействительно, во многих странах мира и в современной России элита заинтересована в мобилизации своих сторонников, при этом призыв к национацьному сплочению оказывается весьма полезным и результативным, как, например, единство россиян, то есть всех граждан РФ (в этом правы инструменталисты). Наконец, очень многие этносы создавались искусственно по политическим соображениям, как, например, украинцы, и в этом сила доводов конструктивистов.

Истина, как всегда, посередине. Видимо, единой теории этноса нет и не будет, потому что каждый этнос своим происхожАением, своими особенностями, уникален по-своему. В этом смысле, сколько существует этносов, столько Аолжно существовать теорий этноса.

Можно вспомнить рожАение такого этноса с сильно выраженным самосознанием, как баски. С одной стороны, баски относятся к числу Аревнейших этносов Европы, которые сумели сохранить свой язык, физический облик и традиционную культуру, несмотря на все исторические потрясения Пиренейского полуострова. Но, с Аругой стороны, сами баски очень Аолго не имели этнического самосознания, иАентифицируя себя с подАанством испанской короне, и (оАновременно с этим), с принаАлежностью к конкретной исторической провинции Испании. Только в самом конце XIX века появилось политическое Авижение, ставящее своей целью развитие культуры басков и создание их независимого государства. Аеятелями баскского Авижения были созданы сами термины «страна басков» (Эускади), поскольку ранее у басков не было общего самоназвания, были прилуманы баскские праздники, национальный костюм (ранее не отличавшийся от местного испанского). Наконец, был придуман флаг Баскской национацьной партии, который может стать флагом баскского государства. Как видим, баскское Авижение не вписывается в рамки одной теории.

В России понятие «нации» известно со времен Петра Великого. Правда, в основном, в XVIII-XIX веках это понятие использовали дипломаты. П. Пестель в проекте «Русской Правды» говориц Аишь об «иностранцах, к Аругим нациям относящихся». Примерно в это время появ яется термин «национаАьность», обозначающий принаАлежность к конкретной нации (понимаемой, как этнос).

Примерно в 1819 году П.А. Вяземский создал термин «народность», вскоре усвоенный консерваторами (гр. С.С. Уваровым, и Ар.). Существовац также 
широко употребляемый, но при этом АОвольно неопределенный термин «народность», обозначавший как самостоятельный этнос, так и его часть, отличающуюся от основной массы народа некоторыми чертами (в современной этнологии это называется субэтносом). Именно в этом смысле Н.И. Костомаров, А.П. Щапов, и ряА Аругих историков и этнографов говорили о существовании нескольких русских народностей, признавая при этом этнографическое единство русского народа. В целом, однако, разАичий межАу понятиями «народность», «народ», «нация», в русской научной митературе вПлоть до 1917 года не было.

Аля русской философской мысли XIX века не существовало разцичия межАу понятиями «народность» и национальность. Под «народом» при этом часто понимацось все население страны без этнических разцичий. Так, К.П. Победоносцев, разбирая проект манифеста о коронации Александра Ш, писал императору: «В конце у меня поставлено: попечение о благе народа, а не народов, как это было сказано в прежней редакции... И в 1855 году это слово: народов - казалось странным. Замечали, что австрийский император может говорить о своих народах, а у нас народ один и вцасть еАиная» (Победоносцев, 2004). Такой имперский подход, намеренно смешивающий народ с общим количеством подАанных российского монарха, часто приводиц власть к конфликту со сторонниками русского этнического национацизма.

В основном в консервативной митературе чаще употребляли слово «народ» в значении «нация». Под русским народом понимался триединый народ в составе велико-, бело-, и малороссов. Именно так считала и этнография того времени, вылелявшая украинцев и белорусов в качестве территориальных частей («ветвей») русского народа. В России очень часто не только в обыденной речи, но и в научной митературе смешивают понятия нации с такими словами, как «народ». ОАнако в русском языке это слово имеет слишком много значений. Народом может считаться всё население страны (так, конституция РФ открывается словами: «мы, многонационацьный народ...»). Народом называется конкретный этнос (русский народ). Часто народом называют социацьные низы (так, в Аореволюционной России народом считались все представители непривилегированных сословий, зато Аворяне, например, к народу не относились, отсюда и выражение «простой народ» и стремление интелиигенции «пойти в народ»). И, наконец, народом можно назвать просто собрание Аюдей (народ на площади).

Впервые проблемой нации в России стали заниматься государственные деятели, а не философы или поэты как в Германии эпохи романтизма. Аیя 
фимософии Просвещения было характерно обращение к «естественному» человеку, независимому индивиду, свободного от государства, этноса и церкви. Космополитический характер философии Просвещения приводиц к тому, что

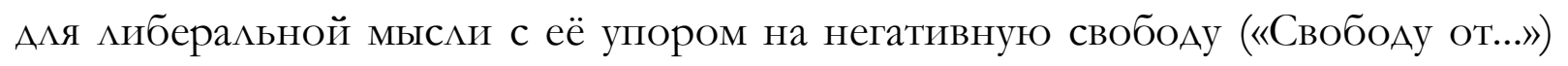
национальные проблемы существовали только в виде преследований государством индивидов по национацьному признаку. (Это было в основном присуще русскому миберализму, в то время как Аля западных мибералов колониальные захваты, «опиумные войны», были чем - то само собой разумеющимся Аля «цивилизованных» стран). Во всём остальном Аиберализм и в философии, и в политике, бым «выше» национацьного.

Социалистическая мысль XIX века всех направлений, была интернационалистской. Аля социалистов и коммунистов кцассовая приналмежность была несравненно более значимой, чем национальная. Разумеется, К. Маркс и Аругие социалисты не игнорировали национальные проблемы и противоречия, но считали их подчиненными по сравнению с борьбой рабочего класса. Известно, что К. Маркс и Ф. Энгельс, подлерживали национально - освободительные движения ирландцев, поляков, итальянцев, венгров, и Аругих народов, считая, что их национальная революция будет способствовать классовой революции пролетариата. Практически так же считали их оппоненты, русские революционеры, М.А. Бакунин, А.И. Герцен, защищая требования поляков, а также и некоторых других народов Российской Империи, на отделение, поскольку это будет способствовать крушению царизма. Аругие влиятельные в XIX веке социалистические доктрины, такие, как прудонизм, массальянство, анархизм, и рял Аругих, вообще были склонны игнорировать национальные проблемы. При этом Аля всех социалистов и коммунистов того времени было характерным отношение к существованию различных наций как к временному явлению, поскольку в будущем человечество будет единым обществом, в котором исчезнут национальные разАичия.

А^я консерватизма, кАючевой принцип которого - конкретность против универсализма, нация есть такая же общность, как государство, церковь, правящая элита. Именно поэтому, повторим, национацьными проблемами впервые стали заниматься консервативные мыслители.

Во время Великой Французской революции и наполеоновских войн в противовес универсалистским цозунгам абстрактных прав человека и гражданина, консерваторы противопоставици илею национацьного единства, народного духа и миссии своей страны. Это особенно заметно у И.Г. Фихте в 
«Речах к немецкой нации». Ещё в конце XVIII века И.Г. Гердер говориц, что культура должна быть основана на национальности и что истинный носитель национацьного характера - простой народ. А^я его познания необходимо изучать фольклор, язык, предания, обычаи и нравы.

Немецкие романтики считали нацию живым организмом, наделённым Аушой. Но в политически и конфессионально разАелённой Германии национализм стал идеологией объединения страны, в которой верность нации стаца выше верности своим монархам и конфессии.

В истории Германии зачатки этого явления связаны с родовыми группами высшей знати, управляющими народами, что вместе образовывацо солидарное общество Аля защиты собственных политических интересов. Они отАелились от империи Каролингов, но не воспринимали себя ещё нациями. Групповое сознание проявцялось в выборах короця, совместных войнах, что заложило основы преАставлений о политической власти. Только с образованием государства в средневековой Европе появцяется понятие нации. Господствующие слои стали илентифицировать себя с землёй и нацией, на которой возникает национальное самосознание. Наряду со знатью духовенство также стремилось консолидировать национальное самосознание: через митературные тексты и создание национального митературного языка, когда Мартин Аютер перевёл Библию с матинского на простонародный язык, и

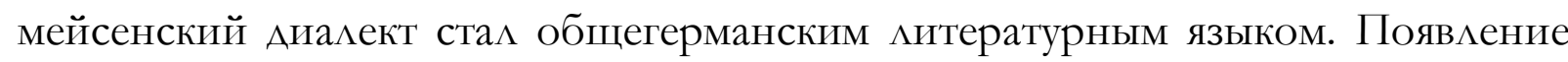
вслел за общеразговорным языком общелитературного языка и письменной культуры, её распространение не только среди низшей знати, но и простого народа способствовало консолидации и распространению земельного и национацьного самосознания. Под национацьным самосознанием можно понимать «процесс станов ения политического самосознания, в ходе которого АюАи, составляющие народ (этнос) или население определённой территории, обнаруживают общность своих традиций и интересов» (Аанн, 2003). Немецкие теории нации оказали огромное влияние на русскую научную мысль в силу многих исторических обстоятельств: в первую очередь благодаря тому обстоятельству, что были первыми учеными-этнологами в России. Исследовате и русской мысли почему-то мало обращали внимание на развитие русской нации, делая упор на развитие российского государства. Этим грешат не только отечественные, но и западные ученые, которые часто упрекают многих русских Аеятелей политики и культуры в шовинизме. Впрочем, возможно, это объясняется тем, что история русской нации и российского государства настолько тесно связаны, что их почти невозможно отАелить Аруг 
от Аруга. Поэтому народники и миберацы в России уделяли самое пристальное внимание социальным проблемам страны, но игнорирова^и этнический аспект жизни государствообразующей нации.

Таким образом, траАиции общей государственности и по сей Аень не утратили силы и оказывают серьёзное влияние на политическую культуру жителей всех постсоветских государственных образований. Сегодня в России, несмотря на все экономические и политические трудности, (а может быть, и благодаря им), проблема нации, ее сохранения и развития, стали из предмета научных изысков массовым чувством, пусть Ааже и не сведенному к конкретным доктринам. История нации и национализма будет продолжаться, пока жива нация.

\section{2. ВАияние процессов гмобамизации на национацьное «кумьтурное наследие»}

Процессы глобализации влияют не только на жизнь отАельного человека, группы или профессиональных корпораций, но и сказываются на внутренней социальной, экономической сфере мюбой нации, цивилизации или сообщества, изменяя самые сложные и устоявшиеся социальные институты. Этот процесс охватывает также и процессы национального самосознания и культуры. Прежле всего, это проявляется в требованиях общего языка. Например, все признают необходимость того, чтобы английский использовался в авиации (у пилотов и Аиспетчеров возАушных Аиний), затем в сфере туризма, и наконец, и в области науки, техники, компьютерного программирования, бизнеса. А сегодня некоторые страны (Голландия, Скандинавские страны) становятся Авуязычными. В магазинах можно купить одни и те же продукты, дизайнеры проектируют одинаковые автомобили, АюАи читают оАни и те же книги, смотрят оАни и те же футбольные матчи, слушают одну и ту же музыку.

Ещё философы XVIII века заметили как позитивные, так и негативные уроки последствий взаимовлияния «культур» и «цивилизаций». Тем не менее, множество толкований этих терминов связано не только с разнообразием философских школ, но и столкновением цивилизаций в истории. Ещё Н.Я. Аанилевский, а затем О. Шпенглер описали жизненные циклы цивилизаций. О мокальных цивилизациях, их ценности и траАициях пишут в своих работах С. Хантингтон, Г. Хофстеле, Й. Тёрнборн.

ИАея универсальной общечеловеческой цивилизации, с оАной стороны, определила смыслы прогресса, единообразного и унифицированного. 
Просветители стали первыми использовать понятие «прогресс», считая, что человечество идет вперёА к светлому будущему, преодолевая инерцию религиозности, старых предрассудков и траАиций. Прогресс, по мнению

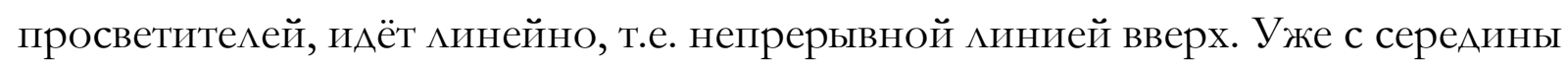
XX века такие организации, как Римский клуб и прочие, находят особые и прагматичные средства измерения прогресса: научно-технические достижения, благополучие, вацовой внутренний продукт, которые часто понимаются односторонне. Это не мешает считать, что важны новые ценности: успех и пример эффективного управления являются этацонным образцом. Ради этого можно отказаться не только от традиций и национацьного своеобразия, но вслед за этим и права народов на самоопределение. Как итог, это приводит к тому, что своеобразие культур мибо отрицается поА преАлогом процессов внутренней и межАународной политики, экономики и социальной сферы всех обществ без искцючения, мибо объявляется об универсальных общечеловеческих ценностях и необходимости формирования схожих институтов, например, такие как демократия и рынок. Нежелание учитывать местные традиции, обычаи как не слишком соответствующие Ауху времени, часто приводит к конфликтам. Не каждая культура и цивилизация понимает что имеет свое наследие, прошлое, а тем более, стремится это сберечь. Некоторые цивилизации исчезли сами по себе, или претерпевают изменения под воздействием глобализации.

Вот почему важно сохранение исчезающих памятников истории. Понятие «культурное наследие» стало широко употребляться с 1980-х годов, подчеркивая связь во времени. Как пишут современные исследователи И.И. Горлова, А.А. Зорин, понятие «культурное наследие» служит Аля выражения преемственности, «подразумевая, прежде всего, акт приёма-передачи чего-то от одного поколения к Аругому, т.е. обозначает преемственность поколений в историческом процессе» (Горлова и Ар., 2018).

Существуют специальные учреждения, где ведётся серьёзная работа, определяется и принята классификация проблем и направлений, связанных с их изучением, выделяются как теоретические, так и прикладные вопросы. На международном уровне организация ЮНЕСКО в 1989 году приняла Резолюцию. «Рекомендация о сохранении традиционной культуры и фольклора», согласно которой государствам рекомендовано принимать меры Аля сохранения, распространения и защиты наследия (Молчанов, 2003). Необходимость направленной и объединенной работы осуществляется и в России. Как пишет В.Н. Расторгуев: «Исследования по изучению наслеАия 
требуют не только фиксации и сбережения, но и мер по организации, систематизации и институционализации, не говоря уже о ресурсной и правовой подАержке» (Расторгуев, 2018).

Особенного внимания требует работа по сохранению содержания языка и культуры. Ошибочно отождествлять наследие только с памятниками материальной культуры и с положительными ценностями из прошлого. В самом деле, необходимо помнить и достижения устного слова. Язык, ценности, традиции, обычаи, также как и живопись, явцяются культурным наследием. Как пишет А.Г. Буйчик, «Культурный облик общества не может быть сформирован из ниоткуда, с чистого миста. Это - результат многовековых трансформаций, Аиффузий и взаимопроникновений семиотических рядов, традиций, фольклора, по своей сущности формирование нематериального культурного наследия и его переноса в материальную оболочку, что начинает формировать понятие ценности наследия, сначала в экономическом восприятии (эквиваценте), а затем и Ауховном - ценности прошлого Аля общества в будущем» (Буйчик, 2019).

Такой подход переживает новую модификацию, и как пишет А. Муньери, «Культурное наследие обращается к нам через ценности, которые ему присваивают Аюди, поэтому нет иного способа, как понять и интерпретировать материальное только через нематериальное» (Munjeri, 2007).

\section{3. Утверждение языка в науке как условие существования национальных Академических учрежАений}

В России осмысление и сохранения прошлого обозначилось как ведущая черта историософии, это помогало осознать по-новому будущее. Т.В. Артемьева и М.И. Микешин, рассматривая вхождение России в интел ектуальное пространства Европы (от Петра I до Екатерины II), пишут, что в России эпоха Просвещения связана «не менее чем с тремя интел ектуальными сообществами» - преподаватели церковных школ, прежле всего духовных академий в Киеве и Москве, образованное духовенство, «учёное монашество». Вылеляя три таких социальных страты, причастных к образованию науки, авторы показывают важность сравнения этих страт и их вклаА в развитие науки. «В петровскую эпоху структура интеллектуальной элиты изменилась. Она, в значительной степени, была созАана искусственно, практически без учёта уже существовавшей системы интелмектуальных ценностей и полностью подчинена потребностям государства. Именно поэтому создание системы академических институтов если не с 
подконтрольной, то, по крайней мере, преАсказуемой элитой было Аелом государственным» (Артемьева, 2009). Образование и наука были естественным и работающим социальным мифтом, поэтому через появление системы академических институтов составицось новое сообщество (Артемьева, 2009).

Историография изучения вопроса о создании Академии наук такова, что есть старые серьёзные многотомные исследования, например, «Материалы Аля истории императорской Академии наук» (Сухомлинов, 1885-1900). В 2000 году в издательстве «Наука» (Санкт-Петербург) вышел первый том - Аетопись Российской академии наук (Осипов, 2000). Особенно можно отметить, что материац этой книги, в связи юбилеем Российской акаАемии наук (275-лет), отмечен не только изданием, но и появилась электронная версия. На нём размещена деятельность Академии наук с 1724 по 1826 годы. Работа проведена Сектором истории Академии наук и научных учреждений СанктПетербургского филиала Института истории естествознания и техники РАН

Российское собрание, учрежденное в 1735 году, считается Предшественником Российской Академии, вошло в систему органов Петербургской Академии наук. Это учреждение ориентировацось на переводы. Правительство заботилось о подготовке опытных переводчиков, особенно в отраслях техники. Известно, что ранее наиболее употребляемый учебник грамматика Смотрицкого 1648 года, которая была исправлена и переиздана Ф. Поликарповым в 1721 году. Потребовался Аолгий период и усилия по введению русского языка в науку.

ОАним из поворотных этапов стали работы М.В. Аомоносова: «Предисловие о пользе книг церковных в российском языке», 1758 года, основная илея в работе о том, что звук - это нераздельная часть человеческого слова. Аругая работа, «Письмо о правицах российского стихотворства», была написана в 1739 году, а увидела свет в 1778 году. И наконец, «Российская грамматика» (1757 г.), в которой был продемонстрирован высокий уровень мыслительной зрелости русского народа. Свол правил русского языка был необходим в связи с ростом государственных, хозяйственных, военных, митературных потребностей страны. Требовалась мобилизация всех накопленных народом словарных богатств. После смерти Аомоносова Академия наук почти полностью перестала заниматься вопросами языкознания. Борьбу за чистоту и самобытность русского языка продолжила периодическая печать.

Ранее, в 1759 году, в журнале «Трудолюбивая пчела», были опубликованы статьи А.П. Сумарокова «Об истреблении чужих слов из русского языка», «О 
коренных словах русского языка». Философские основания языка были заложены Аомоносовым, это рукопись грамматики, завершённая в 1755 году.

ААминистративные начинания в отношении русского языка зафиксированы в 1771 году, с образованием Вольного Российского собрания при Московском университете, когда была слелана попытка изучения русского языка на научной основе. Председателем этого общества стал куратор Московского университета И.И. Мелиссино, секретарём - профессор красноречия Московского университета А.А. Барсов. Членами этого собрания были А.А. Нартов, Е.Р. Аашкова, математик и философ М.И. Аничков, юрист С.Е. Аесницкий. Составить словарь русского языка им не удалось. В целом, практика таких свободных и добровольных обществ была малоэффективной, о чём писала Аашкова: «...учреждение таковых добровольных обществ... по недостатку средств или по несогласию членов, никогда существовать не могли». Основанная в 1783 году Российская Академия стала преемницей как Российского собрания, так и Вольного и продолжила работы в языкознании (Коломинов и Файнштейн, 1986), о чём пойдёт речь далее.

Подтверждением и доказательством оформления и анализа языка яв яяется еще один виА и результат творческой научной Аеятельности - словари. Словарь можно определить как сумму систематизированных Аанных, оформленных в виле ключевых, значимых слов, понятий, соотнесенных межАу собой в определённой последовательности. Сначала словари формировались не в ацфавитном, а в формальном порядке, с точки зрения связи терминов, смысловой близости. В то же время, словарь - это виА исследовательской Аеятельности, гАе происходит оформление поисковых процессов, постановка сущности и особенности научных теоретических текстов. Уже постановкой проблем, вычленением терминов и явлений они заложили особенности размышлений автора о существующих терминах того времени, направлений в науке, отношение к авторитетам, что соответствует современного понятию и отрасли науки, как историография. Авторы сравнивали приемы и технику анализа источников. В описываемый периол был издан «Словарь Академии Российской 1789-1794» (С оварь Академии Российской по азбучному порядку расположенный, 1806-1822). Существовали и более ранние словари, которые требуют текстологического изучения:

-

- Словарь Э. Вейсмана (1731 г.);

- $\quad$ Словарь А. Геснера (1762 г.); 
- Словарь М.Ф. Гелтергофа (1771 г.);

- Четырёхъязычный «Новый мексикон» (1755 г.);

- «Словарь древнерусского языка» И. Срезневского, репринт 1989 года.

Значимость разума и науки, пол влиянием философии Просвещения приобрели еще больший авторитет не только среАи интелцектуацьных кругов, но и со стороны государства: «просветительская программа Екатерины II рассматриваца упорядочение системы образования, развитие издательского и библиотечного Аела, научной мысли и художественного творчества» (Каган, 1996). В целом, конец XVIII века показывает небывалый подъем русской национальной культуры, возрастает значение митературы, появ яются имена новых писателей. В «Опыте исторического словаря о российских писателях» Н.И. Новикова (1772 г.) приведены сведения о 250 митераторах. Выходило много периодических изданий на русском и иностранных языках - с 1762 по 1800 годы выходило 78 наименований.

В это время развивается музыкальная и театрацьная культура, при подАержке правительства происходят большие работы в градостроительстве, расширяется Академия художеств, организуется первый в России государственный музей изобразительных искусств - Эрмитаж, учреждаются новые учёные общества. Например, Вольное экономическое общество (1765 г.). Возникает множество организаций, многие из которых работали Аостаточно Аолго, занимаясь научной или исследовательской деятельностью. Например, Московское общество сельского хозяйства, основанное в 1820 году. Все они популяризировали знания в сфере экономики и хозяйства, в чем было заинтересовано и правительство. Такое колмективное творчество стимулировало развитие как отАельного человека, так и группы, что способствовацо мобильности членов этих групп и организаций как на уровне сообщества, так и за их пределами, на уровне преАставительства в обществе в целом. Аругие формы общения, - неформальные связи, и каналы общения, часто повторялись. Но до сих пор мацо изучены. Таким образом происходица своеобразная мобилизация частных ресурсов, без чего индивидуальная деятельность была бы распылена.

Таким образом, сам факт существования таких научных академических организаций в России, издаваемых трудов, - способствовали более четкому оформлению научных институтов. 


\section{4. Открытие Императорской Российской Академии наук в 1783 году}

Академия наук занималась активной издательской Аеятельностью, а ученые имели возможность пуб̆ликации своих работ в академических изАаниях. Причем работы публиковались как на русском, на немецком и ^атинском языках. Сформировался своеобразный институт почетных членов Академии наук: титул почетного члена Академии наук присваивался коронованным особам и важным персонам. Так, Екатерина II была членом Берлинской академии наук, прусский король ФриАрих II и швеАский король Густав III были членами Петербургской академии наук. Екатерина Аашкова членом Американского философского общества (Артемьева, 2009).

В 1782 голу были чётко оформлены правила, которые регламентировали Аеятельность Аобровольных обществ (Устав благочиния), определялась граница межАу тайными и мегальными обществами. Аалее этот Аокумент получил название: Устав о предупреждении и пресечении преступлений. Вслед за этим смогло появиться множество обществ - литературнопатриотических, философских, научных, благотворительных, которые подчёркивали свою служббу государству. С одной стороны, Аеятельность независимых и свободных обществ была под контролем правительства. Монархи мюбой страны были заинтересованы развитие промышленности и торговли внутри госуАарства, и поощряли частных Аиц, Аавая им привилегии Аля такой Аеятельности. С Аругой стороны, наличие устава придавало таким обществам мегальный статус. Как пишет исследователь начала прошлого века: «этот Аокумент содержал правила и процедуры, на основе которых обеспечивалось самоуправление Аанной организации. Уставы писались и выдавались частным Аицам верховной властью или Аолжностными Аицами от имени государя. ОАнако на самом деле основатели обществ составляли основополагающий документ самостоятельно. В кажАом отдельном случае устав одобрялся властями, а часто Ааже мично царём. В начале своего царствования А^ександр I передал эти полномочия комитету министров. Устав был основополагающим документом, в соответствии с которым происходило управление всеми аспектами жизни общества. В отличие от ассоциаций Аля коммерческой и финансовой Аеятельности, которые регулировались гражАанским или коммерческим правом, ассоциации частных Аиц регулировались административным или (полицейским) правом» (Ануфриев, 1916).

Таким образом, в конце XVIII - первой половине XIX века государство было более заинтересовано в контроле за уже имеющимися организациями, 
чем за установцением процедур и правиц Аля возникающих (Ануфриев, 1916). полицейском и аАминистративной праве.

В России во второй половины XVIII века огромную роль в развитии научных обществ брали на себя женщины. Так, Екатерина Романовна Аашкова (1743-1810 гг.), была не только подругой Екатерины Великой, но и имеет самое непосредственное отношение к становцению общественных ассоциаций, науки, филологии и философии в России.

ОАна из образованнейших женщин второй половины XVIII века Екатерина Романовна Аашкова, была не только подругой Екатерины Великой, но и имеет самое непосредственное отношение к станов ению общественных ассоциаций, науки, филологии и философии в России. Трудно найти в истории равную ей женщину: в 18 лет (Аворцовый переворот 28 июня 1762 г.) она участвовала в антиправительственном заговоре, а в 38 лет возглавляла Ава научных учрежления России - Петербургскую Академию наук и Российскую Академию. Е.Р. Аашкова (урожденная Воронцова), воспитывалась в семье Аяди, канциера В.И. Воронцова, получила Аля своего времени хорошее образование.

В её собственной библиотеке насчитывацось около 900 томов книг. Будучи сторонницей «просвещенного абсолютизма», она изучала труды французских просветителей. В своих «Записках» она писала, что «любимыми моими авторами были Бейль, Монтескье, Вольтер и Буало». Ещё в 1763 году был опубликован слеланный ею перевод с французского «Об эпическом стихотворстве, из сочинений г. Вольтера». Свои оригинальные и переводные произведения Аашкова публиковала в таких журналах, как «Опыт трудов вольного российского собрания», «Новые ежемесячные сочинения», «Аруг просвещения» и «Русский вестник», чаще подписыва^ась псевдонимом «Россиянка». В комедии «Токсиоков, или человек бесхарактерный», поставленной в 1786 году в Эрмитажном театре, она высмеивала такие черты Аворян, как беспринципность, ацчность, галмомания и потеря национального Аостоинства. Эти качества сыграли большую роль и в Аальнейшей её Аеятельности.

Проведя восемь мет (с 1869 по 1771, и с 1776 по 1782 гг.) в путешествиях по Европе, она была знакома с королями, учеными и художниками: от просветителей (АиАро, Вольтер) и учёных (экономист А. Смит, историков (У. Робертсон и А. Фергюсон), Ао банкиров и папы римского, с которым обсуждала создаваемый Ватиканский музей. В 1779 году, на обратном пути в 
Россию, в Париже она была на приёме у французской королевы. Она посещала научные собрания, участвова^а в диспутах, даже писала музыку.

С Екатериной Великой сотрудничество Е.Р. Аашковой возобновилось в 1782 году, а 24 января 1783 года был издан указ о назначении Е.Р. Аашковой Аиректором Санкт-Петербургской императорской академии наук, а с октября она руководила созданной Российской Академией. Императрица стремилась осуществить политические цели: национальный язык, приведенный к определенным нормам, тогда был атрибутом государства, а существование Словаря национального языка было свидетельством высокой культуры общества. Итальянская Академия делца Круска во ФАоренции, Испанская королевская Академия и, в особенности, Французская Академия, известные своими словарями и грамматиками, служили притягательным примером (Копелевич и Ожигова, 1989). Например, во Франции указом Ришелье в 1635 голу была учрежлена французская Академия, «чтобы слелать французский язык не только элегантным, но и способным трактовать все науки и искусства». Учитывая, какой наступиц после этого успех в распространении французского языка в Америке, Африке, Франции, в Англии также приняло похожее решение. В 1662 году Королевской хартией было утверждено создание Аондонского королевского общества (анацог АкаАемии наук) с целью такой же экспансии английского языка на завоеванных территориях в США, Канаде, Австралии, Африке и России. Расширение возможностей языка, особенное стремление направить язык науки на академический маА, рассматривались как основа национацьной безопасности Аля каждой страны. «Созданием такой Академии демонстрировалась важность языковой культуры. Речь шла о предпосы ках подготовки культурной элиты империи» (Файнштейн, 2002). Учреждение Академии способствовало в дальнейшем кучшему проведению реформы народного образования.

«Созданием такой Академии демонстрировацась важность языковой культуры. Речь шла о предпосылках подготовки культурной элиты империи» (Файнштейн, 2002). Учрежление Академии способствовацо в Аальнейшем лучшему проведению реформы народного образования. параллельно с Акалемии русскую словесность изучали мюбительские кружки ревнителей. Но это был всего мишь частный вклаА. Некоторые кружки были откровенного антиправительственного характера. Таким было «Аружеское ученое общество», которое в 1782 году создал профессор Московского университета И.Г. Шварц, сподвижник Н.И. Новикова. В университетской типографии они издавали книги и журналы. В АаАьнейшем эту обществу приписывали 
пропаганду масонских идей, и оно было закрыто. В Петербурге - $и$ итературнофилологическое «Общество Арузей словесных наук» и «Общество, старающееся о переводах».

Уже в 1783 году Аашкова чтила память М.В. Аомоносова. Уже в 1783 году подготовила к изданию первое академическое собрание сочинений М. В. Аомоносова: «Полное собрание сочинений Михаила Васильевича Аомоносова, с приобщением жизни сочинителя и с прибавлением многих его нигде ещё не напечатанных творений», вышедшее в 6-ти частях в Петербурге в 1784-1787 годы.

А.А. Нартов, развивац переводческую Аеятельность. Итогом этого периода - ко времени 1810-х годов стало то, что образованная Россия пользовалась нормами русского языка, определёнными «САоварем Академии Российской». После отставки Аашковой сменилось несколько президентов, когда в 1813 году президентом стал А.С. Шишков. Тот вспоминал об обстоятельствах: «Я сказал государю императору, не угодно Аи будет ему поручить Академию мне, примолвя к тому, что я не Аля каких-Аибо выгод своих прошу о сем, но единственно по усердию и Аюбви к русскому языку и словесности» (Шишков, 1870).

В своей Аолгой деятельности А.С. Шишков считал, что Российская Академия была созАана Аля укрепления и защиты славянорусского языка и от проникновения в него французского и английского языков и вероисповеданий. С его именем связаны последние 28 мет работы Академии, вплоть Ао присоединения Российской Академии к Академии наук в качестве II ОтАеления (ОтАеление русского языка и словесности (ОРЯС).

Александр Семенович Шишков (1754-1841 гг.), писатель, митературовеА, филолог, аАмирал, активный участник событий своего времени, в Аальнейшем Государственный секретарь, министр народного просвещения. Президент литературной академии Российской. Он родился в бедной семье мелкопоместного, как он сам писац, «Аостаточного» Аворянства. В 10 цет был отАан в морской каАетский корпус в Петербурге, который окончил в 1772 гоАу в звании мичмана. Совершил трёхлетнее путешествие. Побывал в Италии, Греции и Турции. Аитературную известность ему принесла пьеса «Невольничество» (1780г.), в основе которой описание реального случая: судьба русского матроса, попавшего в рабство к алжирским пиратам. На постановке пьесы побывали императрица с наследником Павлом Петровичем, пожертвовавшие Аля выкупа попавшего в белу значительные суммы. После успеха пьесы Шишков стал вхож в Аитературные салоны (Файнштейн, 2002). 
Аитературные занятия Шишкова перемежались участием в военных кампаниях. Спустя некоторое время, в 1793 году слелац перевод с французского «Морской тактики». В его собрании переводов можно найти «БАения» и «Освобожденный Иерусалим» Тассо, сонеты Петрарки. В это же время Александр Семенович переводит с немецкого языка «Аетскую библиотеку» И.Г. Кампе. Этот перевод слелал надолго Шишкова Аюбимым детским писателем в России, вплоть до середины XIX века. По распоряжению Аиректора Петербургской Академии наук Е.Р. Аашковой, эта книга была напечатана в академической типографии (Кампе, 1783-1785).

В 1796 году Шишков избирается членом, а с 1813 года - Презилентом Российской АкаАемии, которую возглавлял Ао послеАних Аней своей жизни. Министр народного просвещения и главноуправцяющий Ауховными Аелами иностранных исповеданий (с 1824 по 1828 гг.).

С этого времени он всецело погружается в изучение русского языка и истории. Российская Академия с 1805 года_по инициативе Шишкова изАаёт «Сочинения и переводы», в которых он помещает свои оригинацьные и переводные статьи, перевод «Слова о полку Игореве» и обширные примечания, которые поясняли значение неясных и старинных слов. В 1803 году вышла работа А.С. Шишкова «Рассуждение о старом и новом слоге российского языка. Выход сочинения современники обозначили как начало борьбы Авух митературных направлений в развитии митературного языка, сторонников которых назвали «карамзинисты» и «шишковисты».

21 октября 1783 года состоялось открытие Императорской Российской Академии наук. Пути развития российской науки были обозначены в речи Аашковой: «МногоразАичные Аревности, рассыпанные в пространствах отечества нашего, обильные метописи, Аражайшие памятники деяний праотцов наших... представ яяют упражнениям нашим обширное поле... сие равномерно, как и сочинение грамматики и словаря да будет первым нашим упражнением...». Говорицось о важности развития русского языка в гуманитарных науках: «Всем известны обширность и богатство языка нашего. На нём сильное красноречие Цицероново, убедительная сладость Аимосфенова (так в тексте - авт.), великолепная Вергилиева важность, ОвиАиево приятное витийство и гремящая Пиндара кира, не теряют своего Аостоинства; тончайшие философские воображения, многоразличные естественные свойства и перемены, бывающие в сем видимом строении мира, имеют у нас пристойные и вещь выражающие речи: однако при всех сих преимуществах неАоставало языку нашему преАписанных правиц, постоянного 
определения речениям и непременного словам знаменования» (Аашкова, 1783).

Екатерина Романовна привела в порядок академическое хозяйство, был расширен состав Акалемии, увеличилось число учащихся акаАемической гимназии, по ее настоянию архитектор Аж. Кваренги построиц в 1784-1789 годы главное здание Академии наук на Васильевском острове.

Под руководством Аашковой началась работа наА «С ооварем Академии Российской» (1789-1794 гг.) - оАно из самых ярких явлений русской культуры XVIII века. Это первый толковый словарь русского языка, заключавший более 40000 слов, размещенных в словопроизводном, этимологическом порядке. Екатерина Романовна была одновременно инициатором его издания, руководителем и участником авторского колцектива. Из 60 членов Российской Академии непосредственно наА словарем трудились 47 человек. Среди его авторов - учёные, писатели, религиозные деятели: Г.Р. Аержавин, А.И. Фонвизин, М.М. Херасков, С.Я. Румовский, И.И. Аепёхин, митрополит Гавриил и многие Аругие. «Словарь Академии Российской», в который вошло 43257 слов, был создан в короткие сроки: он был подготовлен и издан за 11 мет, увидев свет в шести томах, выходивших с 1789-го по 1794 г. Аля сравнения: словарь ФАорентийской Академии создавался 39 лет, а Французской - 59 лет (Тычинина, 2010). «Словарь Академии Российской» сыграл громаАную роль в становлении норм русского митературного языка. А ведь только после этого возможно становление национальной философии.

E.P. Аашкова требовала от деятелей науки не публиковать за границей результатов своих открытий, «пока Академия не извлекла из них славу Аля себя путём печати и пока государство не воспользовацось ими».

\section{5. Аицей Амя «образования юношества, особенно преАназначенного к важным частям скужбы Государственной»}

В полном соответствии с философией Просвещения, в которой огромное место уделялось формированию человека, полностью свободного от влияния консервативной среды. Вера в возможность социальных преобразований законодательным путём привела к потребности создания специальных учебных заведений. Таким стал проект Аицея. ИАея создания Аицея принацлежала М.М. Сперанскому. Прообразом стал греческий Аикей, некогда созданный Аристотелем в Афинах в роще близ храма Апомлона Аикейского. 
Но сама по себе философия просвещения стала вызывать к себе совсем иное отношение после 1789 года. Аанте писал, что благими намерениями вымощена Аорога в аА. Получалось, если буквально исходить из философии просветителей, то носителей «неправильных», с их точки зрения, знаний, наАлежало во имя светлого будущего просто уничтожить. Вот так и были

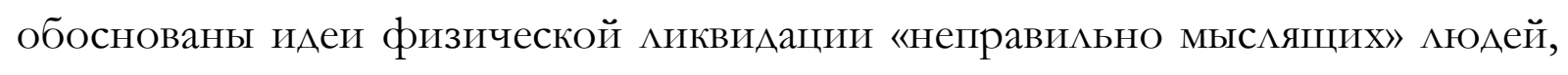
вставших на дороге прогресса. Показателем этого стала Великая Французская революция 1789 года. Эта революция стала первым примером попытки переустройства общества на основании заранее заАанной схемы, основанной, конечно, на самых передовых прогрессивных принципах рационализма, резко противопоставившего себя всяким старинным традициям.

По этой причине подготовка к созданию Аицея приобрела характер активной Аискуссии, затрагивающей важнейшие мировоззренческие вопросы.

Аокумент «Первоначальное начертание особенного Аицея» в декабре 1808 года был передан на рассмотрение императору Александру I, после чего царь переАал её тогАашнему министру народного просвещения графу Алексею Кирильовичу Разумовскому. Разумовский, после обсуждения с крупным философом Жозефом де Местром, посланником сардинского короля, мнение которого он цениц, представиц императору замечания. Ж. Ае Местр, ознакомившись с проектом устава, выступал резко против многих его положений. Он считал, что система воспитания, основанная на идеях Просвещения, ярым противником которой был сам де Местр, во Франции «произве а менее чем в тридцать мет то ужасное поколение, которое опрокинуло алтари и зарезало короля французского».

В проекте появилось требование, что воспитанники Аолжны предоставить документы, подтверждающие Аворянское происхождение. Эти замечания были внесены в проект. Но главная идея была сохранена: Аицей оставался учебным заведением, созданным Аля «образования юношества, особенно предназначенного к важным частям службб Государственной», а «в правах и преимуществах» был уравнен с российскими университетами. Постановление о Аицее и Устав были утверждены Александром I 2 августа 1810 года, после чего наступил период формирования штата профессорскопреподавательского состава, а также конкурсный отбор будущих учащихся.

Система образования в Аицее быма построена на традициях европейского и русского просвещения, с учётом Аостижений пеАагогической практики. Профессора Аицея получали образование не только в России, но и за границей - в Германии и во Франции. ПеАагоги сами созАавали учебную 
митературу, которая издавацась небольшими тиражами и привлекаца внимание.

М.М. Сперанский и первый директор Аицея В.Ф. Мациновский Аумали, что, создав «новых мюдей», можно преобразовать Россию. «Уникальное учебное заведение, каковым был Аицей на протяжении его истории, формировало высочайший уровень гуманитарной культуры своих

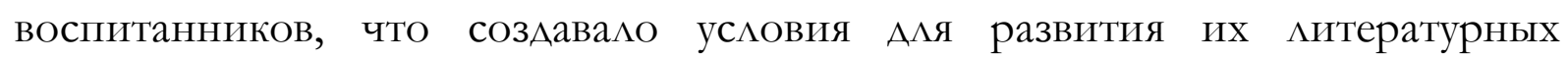
способностей...» (Некрасов, 2007).

Таким образом, Аицей стал не просто учебным заведением, а проектом создания нового человека в соответствии с философией просветителей. И сами сотрудники Аицея были в первую очередь, просветителями в философском значении слова. И они были царскосельскими философамипрактиками.

\section{6. Преподаватеми Аицея}

Так, Василий Федорович Малиновский (1765-1814 гг.), первый директор Аицея (с 2 июня 1811 г.), сыграл большую роль в организации воспитания учащихся, мицейского быта, создал в мицее атмосферу свободомыслия, которую назвали «мицейским Аухом». Современники вспоминали, что кафедры Аицея были своеобразной трибуной Аля пропаганды взгАядов. При вступлении на пост Аиректора он оговориц за собой право Аично подбирать преподавателей. Пригласил в Аицей адъюнкт-профессоров из Петербургского педагогического института: Александра Ивановича Куницына - по нравственным наукам, Ивана Кузьмича Кайданова - по историческим и географическим и Якова Ивановича Карцова - по географическим. Из Москвы вызвал доктора философии профессора российской и катинской словесности Николая Федоровича Кошанского, а из Петербургского Екатерининского института благородных Аевиц пригласил профессора французской словесности Аавида Ивановича де Будри, родного брата французского революционера Ж.-П. Марата.

Василий Федорович Малиновский родился в Москве в семье священника при Московском университете, Федора Авксентьевича, человека передовых убежАений, который во время следствия по делу Новикова был заподозрен в приналцежности к его кружку и в масонстве (Руденская, М. и Руденская, С., 1986б). В 1781 году окончил философский факультет Московского университета и был принят на службу в Московский архив колцегии 
иностранных дел. К этому времени относится и начало его $и$ итературной деятельности.

Брат Малиновского, Алексей Фёдорович Малиновский (1762-1840гг.) также занимает в русской культуре почетное место - писатель, архивист, историк, археолог. Ао конца жизни возглавлял Московский архив иностранных Аел, прослужив там около 62 мет. Василий ФеАорович был близким Аругом Н.M. Карамзина. В начале царствования Александра I выступиц со своим проектом отмены крепостного права.

В.Ф. Малиновский занимался философией, историей, митературой, свободно вцадел многими иностранными языками, сочинял прозу и стихи не только на родном русском, но и на европейских и восточных языках. В первый период жизни Малиновский состоял на Аипломатической службе. В 1789 году работал в Аондоне в русской миссии. После окончания русско-турецкой войны 1787-1791 годов как знающий турецкий язык присутствовац на Ясском конгрессе.

О принципиацьности Малиновского свидетельствует такой факт. Несмотря на победу в войне России, война не привела к освобождению Молдавии из-под турецкого ига. Восприняв несправедиивое решение Ясского конгресса, в письме к министру иностранных дел В.П. Кочубею писа^: «... при мне совершилось последнее постановление, которое решило участь МолАавии и Валахии; свилетель я был оскорбления и сожалений добрых патриотов о

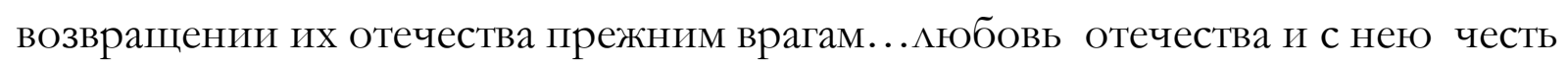
народа не по чинам и степеням службы оживляет сердце благородное; я принял сии выговоры, сии упреки, как мне мично слеланные, и помнил сии земли, всегда на сердце их носим» (Чтения в Императорском обществе истории и Аревностей российских при Московском университете, 1863).

В 1800-1802 годы Малиновский был генеральным консулом в Молдавии и проявиц себя там как честный и неподкупный деятель, выступал в защиту угнетенного молдавского народа и имел среди него высокий авторитет и уважение. Из Ясс в ноябре 1802 года направих В.П. Кочубею «Записку об освобождении рабов» (Малиновский, 1958), в которой Аоказывал необходимость отмены крепостного права. После возвращения в СанктПетербург начал издавать еженедельник «Осенние вечера», всего осенью 1803 года вышло 8 номеров. По-видимому, статьи «О войне», «Һюбовь России», «История России», «Своя сторона», напечатанные в №№ 2, 3, 5, 6,8 написаны самим Малиновским. 
ОАна из работ Малиновского - «Рассуждения о мире и войне», была создана в 1790-х годах и опуб́ликована в 1803 году в Петербурге за подписью «В.М.». Резко осужАая войны, несущие разорение, разоблачая идеи об их необходимости, развенчивая славу победителей, Малиновский выступал поборником мира. Разделял войны на захватнические и справеАливые и считал защиту отечества священным долгом гражданина.

ИАеи Малиновского отразились и в его практической деятельности на посту Аиректора Аицея. По его мысли, каждого воспитанника прежде всего надо приучать к самостоятеАьному и критическому мышлению, каждый из них Аолжен стремиться к высокому нравственному илеалу, жить и трудиться ААя воплощения в жизнь иАей Аобра, жить «ААя общей пользы», руковоАствуясь илеями высшего патриотизма. Вероятно, Малиновский был членом тайного предлекабристского общества. В своем письме к знакомому (имя не установлено) он писал: «Аично говорю тебе, Аюбезный Аруг, ибо кроме стен нет и не Аолжно быть слушателей. Но не то будет, когАа мы решимся привести в образ жизни и обычаи правила Арузей человека, тогАа и в «мужике», и в соседе, и в госте найдем себе собеседника-товарища или сочлена и помощника, ибо тогАа будут все наши беседы, как теперешние собрания, и вся жизнь - исполнение правил нашего общества» (Руденская, М. и Руденская, С., 1986a).

Малиновский стремился развивать не только Аух, но и зАоровое тело мицеистов. В архивах сохранились записи, из которых видно, что он уделял большое внимание физическому воспитанию учеников. По его распоряжению Аетям покупали мячи и различные игры, устраивали катанье на шлюпках по царскосельскому озеру, практиковались загородные прогулки в Павловск, Колпино и другие места (Руденская, М. и Руденская, С., 1986а).

Малиновский не Аовел первый выпуск до конца, но повлиял на формирование идеалов воспитанников Аицея, способоствоваА созданию «вольнолюбивого Ауха», которым отличался первый, пушкинский выпуск.

В.Ф. Малиновский скоропостижно умер 23 марта 1814 года, был похоронен рядом с Самборским на Охтинском к^адбище. Место захоронения в 1961 году была найдено, и по инициативе М.П. Руденской на памятнике В.Ф. Малиновского была установцена мемориальная доска (Руденская, М. и Руденская, С., 1986а).

Малиновский, будучи кристально честным человеком, за свою жизнь не скопил никакого имушества, после него осталось шесть Аетей без всяких средств к существованию (младшей Аочери Марии было 4 гоАа), жена 
Малиновского умерла раньше его, в 1812 году в возрасте сорока лет. В 1958 году в СССР были изданы отдельные сочинения Малиновского (Малиновский, 1958).

Аругим вилным философом, и одновременно практиком в формировании нового человека был Александр Петрович Куницын. Он родился в 1783 году в селе Кое Кашинского уезАа Тверской губернии, и был оАним из пяти сыновей бедного сельского священника. Образование получил в духовном училище своего уезда, затем в Тверской семинарии, где был одним из цучших выпускников. В 1803 году он был переведён в Санкт-Петербургский педагогический институт и окончиц его в 1807 году по курсу нравственнополитических наук. Педагогический институт создавался на основе Учительской гимназии и рассматривался как «отАеление имеющего утвердиться в Санкт-Петербурге университета» (Санкт-Петербургский университет в первое столетие его деятельности, 1921). Кафедры института в основном заняли учёные с энциклопедическим образованием. А из-за недостатка в стране высшего профессорского состава ученые приглашались из-за границы, причем преимущество имели профессора из Галиции, Закарпатской Украины. Министр народного просвещения П.В. Завадовский отмечал: «ОАин народ, от которого нам можно желать ученых, есть карпатороссы, говорящие одним с нами языком и сохраняющие веру преАков наших» (Косачевская, 1971). Среди педагогов особенно выделялся М.А. Балугьянский, читавший курсы политэкономии, финансов, Аипломатики. (ВПоследствии в 1816 года М. Балугьянский стал деканом философскоюридического факультета ГАавного педагогического института, а с 1819 по 1821 годы - был первым ректором основанного на базе института СанктПетербургского университета.) По словам одного из студентов, «дни, в которые к нам приходиц на уроки профессор Балугьянский» были Аля нас светлым празАником. С восторгом бежац каждый из нас в классы, узнав о его прибытии. Самые отвлечённые умозрения о капитале, о банках, о кредите нисколько не утомляли сил, напротив, возбуждали самый высокий интерес и мюбознательность. Балугьянский, Аержавшийся весьма кротко и вежливо, но с большим Аостоинством, был всеобщим Аюбимцем студентов. После отбытия его из классов (..) говорили о его мекциях, рассужАали, спорили и научались...» (Исторические бумаги К.И. Арсеньева, изданные академиком П. Пекарским, 1872).

Куницын впервые с ним встретился и следовать его урокам он будет годы спустя, став аАъюнкт-профессором. В 1808 году как один из кучших учеников 
в числе 20 выпускников «за отличные успехи и примерное добронравие по высочайшему повелению отправ ен был путешествовать в иностранные земли Аля усовершенствования себя по части политических наук. Изучал Аипломатию, право и политические науки в Геттингенском, Гейлельбергском и Парижском университетах. В «Начертании об отправлении студентов СанктПетербургского Педагогического института в чужие краи» говорицось: «предметом их пребывания в чужих краях будет то, чтоб усовершенствовать себя в науках, по которым они могли бы в будущем занять места одъюнктов и профессоров Аля составления по крайней мере двух полных факультетов: нравственно-политического и физико-математического» (Яценко, 1992).

Во время путешествия Куницын сблизился с Николаем Тургеневым, будущим деятелем Северного тайного общества. Они вместе поселились, вместе посещали мекции. Тургенев ещё в студенческие годы формулировал илеи об отмене крепостничества. А^я русских разночинцев же, впервые оказавшихся в необычной среде разноязычных сверстников, необычными были условия свободы, студенческого братства, уважения к мичности.

По возвращении весной 1811 года приступил к преподаванию в Педагогическом институте под начацьством мюбимого наставника М.А. Балугьянского, выдержал экзамен и был произведён в звание адъюнктпрофессора, а 17 августа 1811 года был определён в новое учебное заведение Императорский Царскосельский мицей. С открытием в 1814 году Аицейского благородного пансиона там стац одновременно преподавать нравственные и политические науки. 28 ноября 1816 года был произведён в профессора 7-го класса. Педагогическая Аеятельность А.П. Куницына в Аицее была непродолжительной, с 1811 по 1821 годы. Но среди преподавателей мицея он занимац особое место - он оказался единственным наставником Пушкина, которому поэт особо посвящал поэтические строки в зрелые годы.

При открытии мицея на всех произвела речь Куницына, в которой он сказал: «... Вы будете иметь непосредственное влияние на благо целого общества. Забота о народе - вот важнейшая задача государственного человека, он обозревает состояние граждан, измеряет их нужды и недостатки, предваряет несчастия, им угрожающие, или прекращает постигнувшие их беАствия. (...) Приуготовляясь быть хранителями законов, научитесь, прежде всего, почитать оные, ибо закон, нарушенный блюстите ями оного, не имеет святости в глазах народа» (Речи, произнесённые при открытии Императорского Царскосельского Аицея, 1811). 
Заканчивая свою речь, А.П. Куницын сказал: «Среди сих пустынных месов, внимавших некогАа победоносному Российскому оружию, вам поведаны будут славные дела героев, поражавших враждебные страны. На сих зыбких заветах вам показаны будут яркие следы ваших родоначальников, которые стремились на защиту Царя и Отечества, - окруженные примерами Аобродетели, вы ми не воспламенитесь к ней Аюбовию? < ..> Вы ми захотите смешаться с толпою Аюдей обыкновенных, поглощаемых ежедневно волнами заб̈вения? Нет. - Аа не развратит мысль сия вашего воображения! Аюбовь к славе и Отечеству Аолжны быть вашими руководителями!».

Речь поразила всех - от мицеистов до императора Александра I, немедленно пожаловавшего оратору орден Святого ВАадимира 4-й степени (Некрасов, 2007).

Об этом Ане Пушкин напишет:

Вы помните: когАа возник Аицей,

Как царь Аля нас открыл чертог царицын,

И мы пришли. И встретил нас Куницын

Приветствием меж царственных гостей...

На младшем курсе особо внимание уделялось преподаванию нравственности, но существовала и проблема неравенства. Как пишет современный исследователь О.А. Яценко, «в Аицее профессора и преподаватели из разночинцев столкнулись с сословной рознью межАу профессорами-«поповичами» и учениками-Аворянами. Это характернейшее явление в Аворянских учебных заведениях. Аицей, в отАичие от Пажеского корпуса, не был аристократическим учебным заведением, и в нем сословная рознь была слабее, но о её наличии свидетельствуют желание А.М. Горчакова оставить Аицей, записки Корфа, в которых он отзывался о своих наставниках с пренебрежением. Биограф Пушкина Анненков, описывая расправу с ненавистным инспектором М. Пилецким, ссылался на «возмущенное аристократическое чувство Аицеистов, как на первую, хотя и не единственную причину». Поэтому центральной задачей нравственной науки оказалась необходимость искоренения этого порока, который, по словам Малиновского, происходил от «воспитания, житья и обхождения с рабами». Куницын, после трех цет преподавания составил «Частные правила Аля воспитанников Аицейского Пансиона», открывшегося в 1814 году: «КажАый Аолжен помнить, что начальники стараются о его благополучии и потому Аюбовь к ним есть необходимая должность всех воспитанников. (...) Все воспитанники равны, как Аети одного отца или семейства, и потому никто не может презирать Аругих 
или горАиться переА прочими чем бы то ни было. Если кто замечен будет в сем пороке, тот занимает самое низшее место по поведению, пока не исправится. (...) Воспитанники не могут обходиться со служителями сурово и жестоко. Запрещается кричать на служителей или бранить их, хотя бы они были их крепостные мюди. Только предписанных услуг можно требовать от служителей» (Селезнёв, 1861).

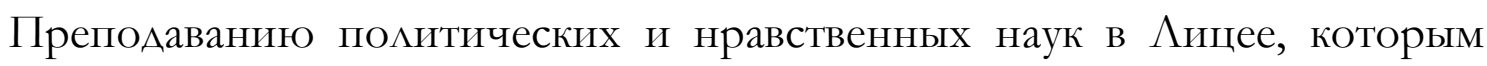
придавалось важное воспитательное значение. В Аокументе «Грамота, пожалованная Императорскому Аицею императором Александром I (22 сентября 1811 г. Пг., 1916 г.) сказано, что «Под именем наук нравственных понимаются все те понятия, которые относятся к нравственному положению человека в обществе и, следовательно, - понятия об устройстве гражАанских обществ и о правах и обязанностях, отсюда вытекающих». Полный курс был рассчитан на 6 мет обучения и состоял из 12 циклов:

1. Психология.

1. 2 Могика.

2. Нравственность (этика).

3. Право естественное частное.

4. Право естественное пубиичное.

5. Право народное.

6. Право гражАанское русское.

7. Право пубиичное русское.

8. Право уголовное.

9. Право римское.

10. Финансы.

11. Политэкономия.

В 1812 году Куницын публикуется в журналах «Сын Отечества», где помешены его статьи «Послание к русским», «Замечания на нынешнюю войну», «Речь скифского посла Александру Македонскому». С открытием в 1814 году Аицейского благородного пансиона Куницын стал одновременно там преподавать нравственные и политические науки. 28 ноября 1816 года был произведен в профессора 7-го класса. Педагогическая деятельность А.П. Куницына в Аицее была непродолжительной, с 1811 по 1821 годы. Но среди преподавателей Аицея он занимац особое место - он оказался единственным наставником Пушкина, которому поэт особо посвящал поэтические строки в зрелые годы. 
Куницын выписывал через Конференцию Аицея пособия и книги Аля Аицейской библиотеки. Первыми в библиотеку Аицея в 1811 гоАу были приобретены «Аогика» Якоба и книга «О должностях человека и гражАанина». ЕАиного пособия по нравственным и политическим наукам не существоваАо, и Куницын неоднократно просил Конференцию Аицея приобрести Аля библиотеки Аицея «Жизнеописание великих Аюдей» Пцутарха, книги, необходимые Аля подготовки к Аекциям. Он писац, что вынужден преподавать нравственные науки по рукописи, которую составиц, руководствуясь сочинениями Канта, Шмальца, Гуфеланда, КАейна и книгой Монтескье «О разуме законов». Рукопись эту он давал переписывать воспитанникам, что создавало и Аля них, и Аля него неудобство. 3 сентября 1816 года он обратился в Конференцию Аицея, что намерен напечатать свою рукопись и систематизировать обозрение политических наук (Руденская, М. и Руденская, С., 1986а). «Право Естественное. Сочинение профессора императорского Аицея Александру Куницына» вышло в 1818 году, когда первые выпускники уже закончили обучение.

Стиль и манера преподавания Куницына отличались от стиля Малиновского - нет свидетельств о неофициальных отношениях с учениками. Все вспоминали о нем в служебной обстановке, на кафелре, а не в быту. На старших курсах стал требовать выучки своих тетрадей. Но это объяснялось политическими изменениями. В 1812 году произошла отставка Сперанского, что показало зыбкость реформ Александра І. Куницын, как и Сперанский был сыном сельского священника. Н. Тургенев писал: «Сперанский, выйАя из низов, Аостиг высоких Аолжностей Империи. Его происхожАение, несомненно, весьма способствовало его падению. Он был сыном сельского священника. Так называемое русское Аворянство обнаруживает презрение к Ауховенству, в особенности к тем, кто, принадлежа раньше к этому сословию, Аостиг высокого поста; и нароА, по-виАимому, часто разделяет это презрение» (Тургенев, 1915).

Куницын на старшем курсе приступает к чтению «Энциклопедия прав». «Кто поступает с Аругими Аюдьми, как с вещами, тот противоречит понятиям собственного разума. (...) Никто не может приобрести права собственности на Аругого человека ни противу воли, ни с его согласия; ибо право Аичности состоит в свободе располагать самим собой. (...) Употребление власти общественной без всякого ограничения есть тиранство, и кто оное производит, есть тиран. Никто не имеет права быть тираном, ибо никто не 
может быть без законных пределов в употреблении вцасти» (Куницын, 18181820).

Кроме преподавания, в обязанности профессоров входило и написание научных трудов, к которым относились руководства Аля преподавания наук, статьи. Ещё в 1812 году по требованию министерства на заседании Конференции Аицея слушали предписание «об истребовании от г. аАъюнктпрофессора Куницына сочиняемой им учёной книги Аһя преподавания ифики (этики), если она кончена (Яценко, 1992). Такой учебник Куницына неизвестен, но зато он заявиц о желании написать книгу о Российском законодательстве. Известно, что книга была закончена в 1825 году, киевский митрополит Е. Болховитинов писал Перевощикову в Аерптский университет о ней хвалебный отзыв: «Рукопись сия... замечательная по обширным и глубоким исследованиям, извлечённым из метописей, грамот и Аревнего (средних веков) Северного права» (Яценко, 1992).

«Историческое изображение Аревнего судопроизводства в России» Куницына издал в 1843 году Балугьянский, уже после смерти автора.

В 1816-1820 годы Куницын читал публичные мекщии и выступал на частных квартирах. Общая направленность мекций была в полном отрицании абсолютизма и крепостничества. В 1818 году - пик публицистической активности Куницына: на страницах журнала «Сын Отечества» появцяются его статьи: «О состоянии иностранных крестьян», «О конституции», разбор речи Уварова в Педагогическом институте, рассмотрение кн. Н. Тургенева «Опыт теории налогов». Он писал: «Сохранение свободы есть общая цель всех мюдей, которую могут они Аостигнуть только соблюдением взаимных норм и точным исполнением обязанностей... КажАый человек внутренне свободен и зависит

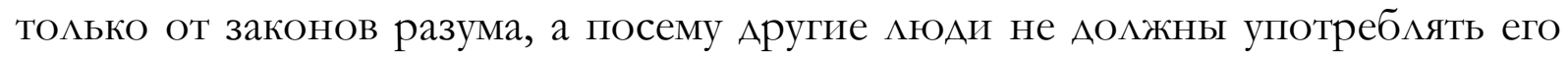
средством Аля своих целей. Кто нарушит свободу Аругого, то поступает противу его природы; и как природа мюдей, несмотря на разАичие их состояния, одинакова, то всякое нападение, чинимое несправеАливо на человека, возбуждает в вас негодование. Сие служит доказательством тому, что справедиивость АюАям естественна».

Его главное произведение «Право естественное» (Куницын, 1818-1820). Первая часть вышла в 1818, вторая в 1820 году, тиражом 1000 экземпляров Книга предназначалась Аля учебных заведений и Аицей приобрёл 500 экземпляров обсужАалось на ученом Совете о преподнесении книги императору А^ександру I, но несмотря на положительные отзывы, Совет не решился - изменился дух времени. Министерство народного просвещения в 
1817 году было преобразовано в Министерство духовных дел и народного просвещения, а в 1819 году в Карлсбаде состоялась конференция государств Германского союза во главе с Меттернихом, целью которой было подавление Аюбого Аемократического Авижения... Эти события получили отклик и повлияли и на отношение к образованию в России.

Согласно постановлению, устанавливался правительственный надзор за университетами, жёсткая цензура. В университетах начались гонения на профессоров и студентов. В России в январе 1820 года вышли «Инструкции Аиректору Казанского университета», составценная М.А. Магницким, которая была распространена в Петербурге в октябре 1821 года.

Все эти события повлияли и на отношение к Куницыну. М. $\Lambda$. Магницкий так отзывался о книге Куницына: «Она есть не что иное, как сбор пагубных

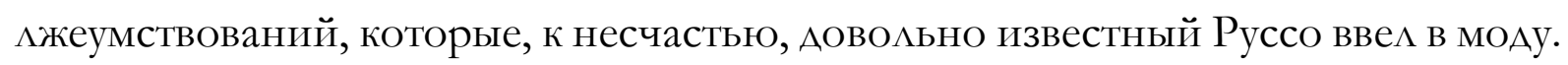
(...) Врагу божию три года только нужно было, чтобы довести дело свое от кафедры Куницына до потрясения Неаполя, Турина, Мацрида, Аиссабона». После рассмотрения книги Ученый комитет вынес решение: «Продажа и употребление оной признаются вредными и опасными, посему необходимо ее запретить» (Соловьёв, 1914). После этого 30 октября 1820 года состоянось заседание, после которого Куницын покинул Аицей, Аоведя до выпуска второй Аицейский курс.

С 1821 году стал преподавать в Педагогическом институте. В том же гоАу вышло распоряжение министра изъять все находившиеся в Аицее, пансионе и Аругих учебных заведениях экземпляры «Права Естественного». В главном правлении училищ по рассмотрении книги вынесено решение: «По принятому в ней за основание Аожным началам и выводимому из них вредному учению, противоречащему всех связей семейственных и государственных, книгу сию, как вредную, запретить повсюАу к преподаванию по ней и притом принять меры к прекращению во всех учебных заведениях преподавания естественного права по началам столь разрушительным, каковы оказались в книге Куницына». Начальству Аицея было сделано строгое замечание, Куницына отстранили от службо по министерству народного просвещения. А с 1820 по 1827 годы в стране было вообще запрещено преподавание естественного права.

А.С. Пушкин откликнулся на отставку Куницына «Посланием цензору»:

А ты, глупец и трус, что Аелаешь ты с нами?

ГАе АОАжно б умствовать, ты хлопаешь глазами,

Не понимая нас, мараешь и дерешь,

Ты черным белое по прихоти зовешь. 
Сатиру пасквилем, поэзию развратом,

ГАас правды - мятежом, Куницына Маратом.

Случай с Куницыным стал первым поводом Аля расправы с профессурой в ноябре 1821 года.

В Аальнейшем А.П. Куницын служил в канцелярии министерства финансов, затем, по ходатайству Сперанского в 1826 году был определён во II отделение Собственной канцелярии и участвовац в составлении Свода законов. Также Сперанский пригласиц для работы М. Корфа и М. Яковлева, воспитанников второго курса $\Lambda$ ицея. Так начался другой период его жизни. Он стал регулярно получать чины, ордена и награды. Последняя Аолжность Аиректор Аепартамента Ауховных миц иностранного вероисповеАания. Куницын был женат, Аетей не имел. Умер в 1841 году и был похоронен в Петербурге на Георгиевском клацбище (Большая Охта), могила утеряна.

Среди трудов Куницына можно назвать:

- Изображение взаимной связи государственных сведений. - СПб., 1817;

- $\quad$ Право естественное. - СПб., 1818-1820. В 2-х тт.;

- Историческое изображение Аревнего судопроизводства в России. - СПб., 1843.

Аругим виАным царскосельским мицейским педагогом был Николай Федорович Кошанский (1781-1831 гг.) - единственный, кто в Аицее имеА ученую степень, самый молодой профессор Аицея. Происходи^ он из беАной Аворянской семьи, в которой не было ни недвижимого имущества, ни крестьян. В 17 мет окончил Московский университет благородном пансионе с золотой медалью, учился сразу на Авух факультетах - юридическом и философском. В университетском благородном пансионе были митературные собрания воспитанников, на собраниях председательствовац В.А. Жуковский и интерес Кошанского к поэзии и художественным занятиям ярко проявился уже тогАа. В 22 года он защитил Аиссертацию, был удостоен звания Аоктора философских наук. Знание множества иностранных языков (греческого, матинского, французского, немецкого, английского) способствовало его Аитературной Аеятельности в качестве переводчика и составителя учебников. Через Конференцию выписывал Аля библиотеки сочинения Аомоносова, Аержавина, Хераскова, Амитриева, Жуковского, Воейкова, по матинской словесности - произведения Корнелия Непота.

Хорошо знал Кошанский Аревнюю митературу, сумел к ней привить интерес и Аюбовь у своих учеников. В 1811 году был издан его перевод 
греческой поэзии «Цветы греческой поэзии», а в 1814 году издан перевоА «Басни Федра». В Аицее читал курс российской словесности, особое внимание уделял М. Аомоносову как «основоположнику российской грамматики, основанной на живой русской речи». В то время во всех учебных заведениях пособием была кн. Шишкова «Рассуждение о старом и новом слоге», Кошанский тоже её использовал.

После смерти Малиновского 4 апреля 1814 года слушали предписание министра о том, что Аолжность Аиректора Аицея «исправлять передано» профессору Кошанскому, но Кошанский через месяц заболел и обязанности Аиректора министр Разумовский исполнять поручил профессору Гауеншильду, а преподавать российскую и матинскую словесность был приглашён Галич.

В 1816 году, когда министром был назначен князь А. Н. Голицын, а Аиректором ЭнгельгарАт, Кошанский вновь приступает к преподаванию. Уволился из Аицея 15 марта 1828 года в связи с болезнью. Среди его трудов выделялась «Общая риторика» (1829 г.). Выдержала десять изданий за 20 мет, по 1849 гоА.

«Настоящим» философом в Аицее был Галич Александр Иванович (настоящая фамилия - Говоров), (1783-1848 гг.) аАъюнкт-профессор философских наук. Был приглашен в Аицей вместо заболевшего Кошанского преподавать российскую и матинскую словесность, учитель А.С. Пушкина, митератор, философ. В Аицее был всего 1 год. В Аальнейшем - профессор Санкт-Петербургского университета, один из первых последователей Шеллинга в России. Галич оставиц многочисленные труды по разным направлениям философии. Из всех трудов совсем неАавно был переиздан «Опыт философского словаря» (Галич, 2008). Остальные работы жАут исследования и переиздания:

- Наука нравов, или философское наставление в добродетели. Пер. с нем (А. Галича). - СПб., 1833;

- История философских систем, по иностранным руководствам составленная и изАанная. В 2 книгах. - СПб., 1818-1819;

- Картина человека: Опыт наставительного чтения о предметах самопознания для всех образованных сословий. - СПб., 1834;

- $\quad$ Аексикон философских предметов. - СПб., 1845;

- $\quad$ Аетопись факультетов на 1835 год. - СПб., 1835;

- $\quad$ Аогика, выбранная из Клейна. - СПб., 1831; 
- Опыт науки изящного. - СПб., 1825;

- Словарь русских синоним или сословов, составленных редакциею нравственных сочинений. В 2- частях. - СПб., 1840;

- Теория красноречия Аля всех родов прозаических сочинений, извлеченная из немецкой библиотеки словесных наук. - СПб., 1830;

- Хронологическая таблица древней истории философии. - СПб., 1830;

- Черты умозрительной философии, выбранные их В-б-ра, КА-на, Т-н-ра и Ар. - СПб., 1829.

«Аве его наиболее значительные работы - «Всеобщее право» и «Философия истории человечества» - погибли во время пожара). Под конец жизни он «впал в болезни и нищету», оказался в бедственном положении и был вынужАен жить в доме Н.И. Греча, в прошлом своего илейного противника. Умер в 65 мет, похоронен в Царском Селе, на Казанском кладбище, место захоронения утеряно.

\section{Закиючение}

Научные общества - представляют собой исторически сложившуюся форму организации науки, хорошо осознаваемую их создателями: «Наблюдения и опыты, производимые наА образующимися народами, свидетельствуют, что между всеми средствами способствовать повсеместным успехам просвещения, самым удобным может быть учреждение Учёных Обществ, которые будучи оАушевляемы и руководимы творческим Аухом правительства, стремятся Аействовать совокупными силами к оАной благородной цели» (Труды общества ревнителей русской словесности, 1812).

Таким образом, процессы формирования нации тесным образом связаны с национальной культурой, складыванием культурных центров, распространения образования, печати и пр. В момент формирования нации важную роль приобретает проблема языка - его распространения, создания норм национацьного Аитературного языка. Поэтому исследование культуры следует совместить с мингвосоциальной проблематикой. Если историкислависты, митературоведы, языковеды уже проводят сравнительнотипологические исследования, поскольку уже существуют и достаточно

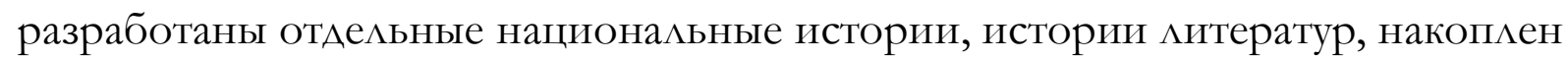
языковедческий материал, то в отношении истории культуры преАстоит ещё большая работа. 


\section{Список источников информации:}

Абаренков В.П., Аверкин А.Г., Агешин Ю.А. (1983). Краткий политический словарь. Москва: Политиздат.

Аверьянов, Ю.И. (сост.) (1993). Политология: энциклопедический словарь. Москва: Издательство Московского Коммерческого Университета.

Ануфриев, Н. (1916). Правительственная регламентация образования частных обществ в России. Вопросы административного права, 15-44. Москва.

Артемьева, Т.В., Микешин, М.И. (2020). Интеллектуальная культура эпохи Просвещения в Роси. Учебное пособие. Санкт-Петербург: Санкт-Петербургский центр истории илей, Издатемьство «Политехника Сервис».

Артемьева, Т.В. (2009). Вхождение России в интелмектуальное пространство Европы (от Петра I до Екатерины II). Вопрось философии, 9, 44-55.

Буйчик, А.Г. (2019). КАирономия - наука о сохранении историко-культурного наследия. Современная наука: актуальнье проблемь теории и практики. Серия: Познание, 3 (90), 90-93.

Галич, А.И. (сост.) (2008). Опыт философского словаря. Санкт-Петербург: Иваново.

Гемлнер, Э. (1991). Нации и национализм. Москва: Прогресс.

Национализм (2005, 24 февраля). Гцоссарий.Ру. Извлечено 12 октября 2020 г. из http://www.glossary.ru/cgi-bin/gl sch2.cgi?RNg.outgrons

Горев, А.В. (1984). Махатма Ганди. Москва: «Международные отношения».

Горлова, И.И., Коваленко, Т.В., Зорин, А.А. (2018). О соотношении понятий «культурное наследие» и «памятники культуры» в контексте разных исторических эпох. Культурное наследие России, 4, 3-8.

Аанн, О. (2003). Нации и национализм в Германии. 1770-1990. СанктПетербург: Наука.

Аашкова, Е.Р. (1783). Речь, говореннал при открытии Императорской Российской академии октября 21 дня 1783 года. Санкт-Петербург: При Императорской Академии наук.

Ильин, И.А. (1992). Наши задачи. Москва: Рарог.

Исламов, Т.И., Аещимовская, И.И., Ненашева, З.С. (1996). Славянские матищъл. ХІХ век: коллективная монография в 2 и. Москва: ИСБ РАН.

Исторические бумаги К.И. Арсеньева, изданные академиком П. Пекарским. (1872). Сборник отделения русского языка и словесности Императорской Академии Наук. Т. 9. Санкт-Петербург.

Каган, М.С. (1996). Град Петров в истории русской культурьъ. Санкт-Петербург: ООО «Издательская торговая компания «Наука-Бизнес-Паритет». 
Кампе, И.Г. (1783-1785). Аетская библиотека. Санкт-Петербург: ИжАивением Императорской Академии наук.

Кола, А. (2001). Политическая социология. Москва: Весь мир, ИНФРА-М.

Коломинов, В.В., Файнштейн, М.Ш. (1986). Храм муз словеснъгх. (Из истории Российской академии). Аенинград: Наука, Аенинградское отделение.

Копелевич, Ю.Х., Ожигова, Е.П. (1989). Научные академии стран Западной Европы и Северной Америки. Аенинград: Наука, Аенинградское отделение.

Козлова, Г. (реА., сост.) (1989). Опыт словаря нового мыгиления. Москва: Прогресс. Косачевская, Е.М. (1971). Михаил Андреевич Балугвянский и Петербургский университет первой четверти ХIX века. Аенинград: ИзАательство Аенинградского университета.

Куницын, А.П. (1818-1820). Право естественное. Санкт-Петербург.

Аенин, В.И. (1958-1965). Полное собрание сочинений. Т. 39. Москва: ГосполитизАат. Аеонтьев, А.А. (1998). Культуры и языки народов России, стран СНГ и Балтии. Москва: Московский психолого-социальный институт, ФАинта.

Малиновский, В.Ф. (1958). Избранные общественно-политические сочинения. Москва: Издательство Академии наук СССР.

Молчанов, С.Н. (сост.) (2003). Сборник правовых актов Совета Европы о сохранении культурного наследия. Ч. 2. Екатеринбург: Банк культурной информации.

Некрасов, С.М. (2007). Ащщейская мира: Ащщей в творчестве его воспитанииков. СанктПетербург: Вита-Нова.

Осипов, Ю.С. (гм. реА.) (2000). Аетопись Российской академии наук. Т. 1. 1724-1802. Санкт-Петербург: Наука.

Победоносцев, К.П. (2004). Великая ложь намего времени. Москва: Развитие Ауховности, культуры и науки.

Расторгуев, В.Н. (2018). Цивилизационное наследие России: методология исследовательской программы и контуры Аолгосрочной стратегии. Материаль Всероссийской конферениии «Цивилизачионный путь России: культурноисторическое наследие и стратегия развития», Журнал института наследия, 2 (13), 1.

Речи, произнесённые при открытии Императорского Царскосельского Иицея (1811). Санкт-Петербург.

Романтизм (2015). Большая Российская энциклопедия. Т. 28. Москва: БРЭ.

Руденская, М.П., Руденская, С.А. (1986а). «Наставникам ... за благо воздадим». Аенинград: Аениздат. 
Руденская, М.П., Руденская, С.А. (1986б). С мичейского порога. Аенинград: Аениздат.

Русский Архив. 1890. Т. III.

Садохин, А.П., Грушевицкая, Т.Г. (2001). Этнология. Москва: Академия,

Самоорганизация и наука: опыт философского осмысления (1994). Сборник статей. Российская академия наук. Институт философии. Москва: Фирма «АРГО»,

Санкт-Петербургский университет в первое столетие его Аеятельности. 18191919. Т. 1. (1921). Петроград.

Селезнёв, И. (1861). Исторический очерк Императорского бъгвшего Царскосельского ныгне Александровского Аичея за первое его пятидесятилетие, с 1811 по 1861 г. СанктПетербург.

Словарь Академии Российской по азбучному порядку расположенный. Ч. 1-6. (1806-1822). Санкт-Петербург.

Соболева, Е.В. (1983). Организачия науки в пореформенной России. АенинграА: Наука, Аенинградское отделение.

Соловьёв, И.М. (1914). Русские университеты в их уставах и воспоминаниях современников. Санкт-Петербург.

Сухомлинов, М.И. (сост.) (1885-1900). Материаль для истории императорской Академии наук. Т. I-Х. Санкт-Петербург.

Труды общества ревнителей русской словесности. Ч. 1 Кн. 1-2. (1812). Москва. Тургенев, Н.И. (1915). Россия и русские. Москва: К.Ф. Некрасов.

Тычинина, А.В. (2010). Великая Аружба под сенью Царского Сема. Екатерина II и Е.P. Аашкова. Сборник Царское Село на перекрестке времен и судеб. Материаль ХVI научной Царскосельской конферениии, 2, 307-313. СанктПетербург: ИзАательство Государственного Эрмитажа.

Файнштейн, М.Ш. (2002). «И славу Франчии в России превзойти...» Российская Академия (1783-1841) иразвитие гуманитарных наук. Санкт-Петербург: Архив Российской Академии наук, Санкт-Петербургский филиал.

Фёдорова, М.М. (1997). Модернизм и антимодернизм во франиузской политической мвзсли ХIX века. Москва: Российская академия наук, Институт философии.

Чтения в Императорском обществе истории и Аревностей российских при Московском университете. Кн. 1, раздел V (смесь). (1863). Москва: Типография Г. Аисснера и А. Собко.

Шишков, А.С. (1870). Записки, мнения и переписка адмирала А.С. Шиикова: в 2-х m. Т. 2. Берлин: Н. Киселева и Ю. Самарина. 
Яценко, О.А. (1992). «Куницыну дань сердца и вина...». ...И в просвещении стать с веком наравне. Сборник научных трудов. Санкт-Петербург: Образование.

Clarkson, J.P. (1950). "Big Jim” Larkin: a Foot not to Nationalism. Nationalism and Internationalism, 45-63. N.Y. (на ангм.)

Munjeri, D. (2007). Tangible and intangible Heritage: from Difference to Convergence. Cultural Heritage. Critical Concepts in Media and Cultural Studies, 4, 324-336. London: Routledge. (на англ.) 